University of St. Thomas, Minnesota

UST Research Online

Spring 2008

\title{
The Evolving Law of Employee Noncompete Agreements: Recent Trends and an Alternative Policy Approach
}

\author{
Michael J. Garrison \\ University of St.Thomas, Minnesota, mjgarrison@stthomas.edu \\ John T. Wendt \\ University of St. Thomas, Minnesota, jtwendt@stthomas.edu
}

Follow this and additional works at: https://ir.stthomas.edu/ocbeblpub

Part of the Business Law, Public Responsibility, and Ethics Commons

This Article is brought to you for free and open access by the Ethics and Business Law at UST Research Online. It has been accepted for inclusion in Ethics and Business Law Faculty Publications by an authorized administrator of UST Research Online. For more information, please contact asle4660@stthomas.edu. 


\title{
The Evolving Law of Employee Noncompete Agreements: Recent Trends and an Alternative Policy Approach
}

\author{
Michael J. Garrison* and John T. Wendt**
}

\section{INTRODUCTION}

Kai Fu Lee earned his doctorate from the School of Computer Science at Carnegie Mellon. While there he developed the world's first practical and accurate speech recognition system (the SPHINX system), which allowed for natural and continuous speech and which could handle tens of thousands of words, multiple voices, and even accents. ${ }^{1}$ Lee first worked at Apple Computer, serving as vice president of the interactive media group that developed QuickTime, QuickDraw 3D, QuickTime VR, and PlainTalk speech technologies. He left Apple to become the vice president and general manager of Silicon Graphics (SGI), where he was responsible for several product lines and SGI's corporate Web strategy. ${ }^{2}$ He later left SGI to join Microsoft.

\footnotetext{
*Professor of Business Law, University of St. Thomas, Opus College of Business.

**Assistant Professor of Business Law, University of St. Thomas, Opus College of Business.

${ }^{1}$ Ed Frauenheim, Who in the World is Kai-Fu Lee?, CNET News.com (Aug. 2, 2005), http://www. news.com/Who-in-the-world-is-Kai-Fu-Lee/2100-1014_3-5814520.html; Verne Kopytoff, Highly Respected Scientist at Center of Battle, Ruling Expected Today on Extending Curb of Ex-Microsoft Exec's Duties at Google until Trial, SFGATE.com (Sept. 13, 2005), http://www.sfgate.com/cgi-bin/article. cgi?f=/c/a/2005/09/13/BUGL2EMMGJ1.DTL\&hw =kai+fu+lee\&sn=001\&sc=100.
} ${ }^{2}$ Biography of Kai-Fu Lee, http://www.google.com/corporate/execs.html\#kaifu (last visited
Oct. 4, 2007).

(C) 2008, Copyright the Authors

Journal compilation (C) 2008, Academy of Legal Studies in Business 
At Microsoft, he served as corporate vice president of the Natural Interactive Services Division (NISD), ${ }^{3}$ where he was a key player in Microsoft's administration. In that position, Lee was

responsible for the development of the technologies and services for making the user interface simpler and more natural. NISD includes technologies and products for speech, natural language, advanced search and help, and authoring and learning technologies. ... [Lee] was the founder of Microsoft Research Asia, which has since become one of the best research laboratories in the world, with a prolific publication and product transfer record. ${ }^{4}$

While Lee was at Microsoft, Google, Inc. recruited him to lead its China research and development center, which triggered lawsuits in Washington and California ${ }^{5}$ and sparked a public relations battle between the rival high-tech firms. On July 19, 2005, the same day that Lee accepted the position of Vice President of Engineering and President of Google China, Microsoft filed for a temporary restraining order and preliminary injunction against Lee and Google alleging breach of an employee confidentiality and noncompete agreement between Lee and Microsoft. ${ }^{6}$ In a press release simultaneous with the lawsuit, Microsoft stated:

Creating intellectual property is the essence of what we do at Microsoft, and we have a responsibility to our employees and our shareholders to protect our intellectual property. As a senior executive, Dr. Lee has direct knowledge of Microsoft's trade secrets concerning search technologies and China business strategies. He has accepted a position focused on the same set of technologies

\footnotetext{
${ }^{3}$ Frauenheim, supra note 1 .

${ }^{4}$ Hua Yuan Science and Technology Association, Events and News, http://www.hysta.org/ event_detail.php?id=135 (last visited Oct. 1, 2007).

${ }^{5}$ See Microsoft Corp. v. Lee, No. 05-2-23561-6 SEA (Super. Ct. Wash. Sept. 13, 2005) (order granting preliminary injunction), http://www.metrokc.gov/kcsc/docs/Microsoftprelim.pdf; Google, Inc. v. Microsoft Corp., 415 F. Supp. 2d 1018 (N.D. Cal. 2005).

${ }^{6}$ Lee, No. 05-2-23561-6 SEA. The Agreement contained the following provision at paragraph 9:
}

While employed at Microsoft and for a period of one year thereafter, I will not (a) accept employment or engage in activities competitive with products, services or projects (including actual or demonstrably anticipated research or development) on which I worked or about which I learned confidential or proprietary information or trade secrets while employed at Microsoft..... 
and strategies for a direct competitor in egregious violation of his explicit contractual obligations. ${ }^{7}$

In response to Microsoft's suit, Lee and Google argued, "This lawsuit is a charade ... Indeed, Microsoft executives admitted to Lee that their real intent is to scare other Microsoft employees into remaining at the company." "Lee stated that in a July 15, 2005, meeting Microsoft chairman Bill Gates said, "Kai-Fu, [CEO] Steve [Ballmer] is definitely going to sue you and Google over this. He has been looking for something just like this, someone at a VP level to go to Google. We need to do this to stop Google." 9

On September 13, 2005, a King County (Washington) Superior Court judge issued a limited preliminary injunction against Lee and Google. ${ }^{10}$ The court found that, although Lee had signed the noncompete agreement, a question for trial remained as to whether there was sufficient consideration for the covenant. ${ }^{11}$ The court also found that "Lee misled Microsoft about his intention to return to Microsoft following his sabbatical and he continued to have access to Microsoft's proprietary information after he decided to leave Microsoft to join one of its competitors without informing Microsoft." 12 The court additionally determined that Lee "assist[ed] Google while he was still employed at Microsoft," 13 that he "worked on products, services or projects" about Microsoft's plans in China, and that he received "confidential, proprietary or trade secret information" regarding Microsoft's China plans. ${ }^{14}$

\footnotetext{
${ }^{7}$ Press Release, Microsoft Corp., Statement from Microsoft Regarding Legal Action Against Google and a Former Executive (July 19, 2005), http://www.microsoft.com/presspass/press/ 2005/jul05/07-19GoogleStatement.mspx.

${ }^{8}$ A Microsoft 'Charade': Google Attacks Lawsuit over Hiring, Int'L Herald Trib., July 29, 2005, http://www.iht.com/articles/2005/07/28/business/google.php (quoting a Google filing with the Washington Superior Court).

${ }^{9}$ Ed Frauenheim, Lee looked up Google, wasn't poached, News.com, July 28, 2005, http://news. com.com/2061-10788_3-5809107.html?tag=nl (quoting declaration of Kai Fu Lee filed with Washington Superior Court).

${ }^{10}$ Lee, No. 05-2-23461-6 SEA.

${ }^{11} I d$. at 7 .

${ }^{12} I d$. at 7-8,

${ }^{13} I d$. at 8 .

${ }^{14} I d$.
} 
The court read the noncompetition and nonsolicitation paragraph of Lee's Microsoft Employment Agreement ${ }^{15}$ narrowly. It found that Lee had given only "general, non-technical advice to Google about doing business in China," which did not violate the agreement, provided that Lee did not "recruit from Microsoft or use any confidential information about Microsoft." ${ }^{16}$ Hence, while Microsoft was entitled to a preliminary injunction restricting Lee's activities, Microsoft had not produced sufficient evidence to enjoin Lee from working for Google and establishing its Development Facility in China. ${ }^{17}$

In the wake of the court's ruling, both sides claimed that they prevailed. Microsoft said, "We are pleased with our victory in court today. The court entered an injunction that restricts the work Dr. Lee can do for Google, preventing him from working on speech, natural language and search technologies, as well as setting the overall research and development course for Google China." ${ }^{18}$ In a posting to Google's official Web log, associate general counsel Nicole Wong stated, "We're thrilled, and he's excited to get right to work on several big things, including recruiting, building our Chinese R\&D center, and related government relations. ... There are some restrictions, but the ruling basically allows Dr. Lee to do what we've wanted him to be able to do." 19

Welcome to the modern world of employee noncompete agreements. Microsoft and Google are in a twenty-first-century clash of the titans in today's multibillion-dollar knowledge-based economy. This is a war about competition and unfair competition, an attempt to balance an employer's desire to protect its business assets and the employee's interest in professional mobility. And it is a delicate balance. Traditionally, courts favored the employee, reviewing noncompete agreements under a common law reason-

\footnotetext{
${ }^{15}$ See supra note 6 for the full language of the paragraph.

${ }^{16}$ Lee, No. 05-2-23461-6 SEA, at 9.

${ }^{17} I d$. at 10 ("Microsoft has not sufficiently shown that it has a clear legal or equitable right to enjoin Dr. Lee, pending trial, from Establishing and Staffing a Google Development Facility in China.").

${ }^{18}$ Press Release, Microsoft Corp., Updated: Statement from Microsoft Concerning Superior Court's Preliminary Injunction Order in Case of Google and Kai-Fu Lee (Sept. 13, 2005), http://www.microsoft.com/presspass/press/2005/sep05/09-13GoogleStatementPR.mspx.

${ }^{19}$ Posting of Nicole Wong to Official Google Blog, Judge clears way for Dr. Lee, http:// googleblog.blogspot.com/2005/09/judge-clears-way-for-dr-lee.html (Sept. 13, 2005, 11:57:00 PST).
} 
ableness test that placed a heavy burden on employers to justify the need for and the reasonableness of any postemployment restraint. This common law approach was complemented by state restraint of trade statutes that limited covenants not to compete to a greater extent than under the common law. Overall, the traditional legal approach to postemployment restrictions, discussed in Parts II and III, was hostile to employee noncompete agreements.

Gradually, however, many jurisdictions adopted a more relaxed approach to restrictive covenants in the employment context. The development of what we will refer to as the modern approach is discussed in Part IV. Under it, many states altered the common law standards, broadening the permissible scope of employee noncompete agreements. Many of these jurisdictions also empowered courts to reform and, thereby, rewrite overbroad restraints on former employees, rather than penalize employers whose noncompete covenants were unreasonable. While traditional standards favored the employee by imposing a heavy burden on employers seeking to enforce restrictive covenants, the modern approach, under which broad noncompete agreements have been allowed in many jurisdictions, represented a shift in the law in favor of employer interests. ${ }^{20}$

A review of the most recent judicial opinions addressing employee noncompete agreements ${ }^{21}$ and some complementary statutory developments reveals a new trend in the law. Discussed in Part V, the opinions suggest a heightened judicial scrutiny of employee noncompete agreements, the effect of which is to restrict the enforceability of employee noncompete agreements. ${ }^{22}$ These recent decisions represent a full-scale assault on the modern approach.

\footnotetext{
${ }^{20}$ We recognize that characterizing the law as favorable to employers or as pro-employer may be oversimplifying the discussion. Strong enforcement of employee noncompetes favors incumbent employers over new or prospective employers. However, from the employee's perspective, strong enforcement can legitimately be viewed as pro-employer. And if one views the law of employee noncompetes as determining the ownership of human capital development in the workplace, then it is appropriate to characterize the law as either favoring the rights of employers or employees.

${ }^{21}$ This article focuses primarily on state supreme court decisions that have doctrinal significance to the law of employee noncompetes and that were issued between 1999 and 2006.

${ }^{22}$ We do not contend that recent noncompete decisions are uniformly in favor of employee mobility. See, e.g., Idbeis v. Wichita Surgical Specialists, 112 P.3d 81, 89 (Kan. 2005) (recognizing referral services as a legitimate interest in justifying physician noncompete agreement); Wood v. Acordia of W. Va., Inc., 618 S.E.2d 415, 422 (W.Va. 2005) (considering nonsolicitation agreement less restrictive of employees' rights and the market than other
} 
A similar and parallel trend has occurred in the doctrine of inevitable disclosure of trade secrets, a theory under which the courts prohibit an employee's subsequent employment opportunities to prevent threatened misappropriation of trade secrets. The doctrine has come under judicial attack, with some jurisdictions rejecting it outright and others severely limiting its application based on policy considerations. The recent change in judicial attitude toward the inevitable disclosure doctrine is discussed in Part VI.

The emerging trend in the law of employee noncompete agreements suggests that courts are generally more inclined to invalidate employee noncompete agreements than under the modern approach and that the law of employee noncompete agreements is becoming more protective of the employee's interest in mobility. This heightened scrutiny of employee noncompete agreements reflects some of the fundamental changes taking place in the economy and in the workplace. Part VII discusses the changing nature of the employment relationship, the evidence of the need for information sharing in the new economy, and the implications these developments have on the emerging law of employee noncompete agreements. Strong enforcement of employee noncompete agreements is not only inconsistent with the emerging information-age employment relationship, where employee mobility is a key feature, but such enforcement may also have detrimental economic effects by inhibiting rapid knowledge transfers that stimulate technological change.

Given the new trend in employee noncompete law and the fundamental changes taking place in the economy, a wholesale reassessment of the traditional common law and modern approaches to employee noncompete agreements is necessary. Part VIII develops our proposed policy framework, outlining the rationale for a new approach to such agreements and the beneficial effects of the proposed change in the law. This alternative framework differentiates an employer's interests in goodwill

postemployment restraints). Some opinions appear to follow the trend we have identified, but the impact of these decisions on the law is unclear. E.g., Montana Mountain Products v. Curl, 112 P.3d 979, 981 (Mont. 2005) (finding employee noncompete agreement unenforceable as overbroad when it effectively prevented the employee from working in his field where he lived, thereby apparently putting some teeth in the third prong of the Montana reasonableness test, which requires a noncompete agreement not to be "so large in its operation as to interfere with the interests of the public"). Other cases clearly follow the trend, as with recent opinions holding employee noncompete agreements to be nonassignable. E.g., Traffic Controls Servs. v. United Rentals Northwest, Inc., 87 P.3d 1054, 1060 (Nev. 2004). 
and trade secrets. Under our proposal, the employer's interest in goodwill, including secret customer lists, would be protected under carefully tailored noncompete agreements. Recent opinions have demonstrated that the common law reasonableness standard can be adjusted to prevent only those forms of postemployment competition that are unfair because of the exploitation of the former employer's customer relationships.

We contend, however, that the present approach to trade secret protection under employee noncompete law creates a serious risk of unnecessarily stifling employee mobility and innovation. Merely adjusting the common law reasonableness test will not adequately protect these important societal interests. Rather, a more fundamental change in the law is required. Under the proposed framework, the mere potential for trade secret misappropriation would no longer be considered a legitimate justification for a postemployment restraint. Noncompete agreements would not be enforceable to protect trade secrets, although proprietary business information would continue to be protected from actual or threatened misappropriation under confidentiality agreements and state trade secret law. More importantly, the courts would be specifically empowered to prevent employment of a former employee based on the inevitable disclosure of trade secrets. Compared to the common law approach to the enforcement of employee noncompete agreements, we believe the inevitable disclosure doctrine provides a more balanced and equitable resolution of the competing interests of employers and employees with regard to trade secrets and postemployment competition. Our proposed framework relies on a carefully framed injunction based on demonstrated necessity (inevitability). Our approach is superior to enforcing a noncompete agreement based only on the potential for trade secret misappropriation, because it supports a climate of employee mobility and information sharing while providing businesses an adequate level of protection for their trade secrets.

\section{NONCOMPETE AGREEMENTS IN THE EMPLOYMENT CONTEXT: THE COMMON LAW APPROACH}

As a matter of public policy, courts have traditionally looked upon agreements not to compete with disfavor. ${ }^{23}$ Such restrictions on employees

\footnotetext{
${ }^{23}$ E.g., Kallok v. Medtronic, Inc., 573 N.W.2d 356, 361 (Minn. 1998) ("In Minnesota, employment noncompete agreements are looked upon with disfavor, cautiously considered,
} 
were prohibited under the early English common law ${ }^{24}$; however, over time, the common law prohibition against noncompete agreements loosened. The courts recognized that such agreements can be legitimate if they serve business interests other than the restriction of free trade. ${ }^{25}$ Thus, agreements not to compete ancillary to an employment relationship have been permitted, subject to a reasonableness requirement. ${ }^{26}$

The common law reasonableness approach is an attempt to balance the conflicting interests of employers and employees as well as the societal

and carefully scrutinized." (internal quotes and citation omitted)). The seminal article on employee noncompete agreements is Harlan M. Blake, Employee Agreements Not to Compete, 73 HaRv. L. Rev. 625 (1960). For recent commentary on the law of employee noncompete agreements, see generally Norman D. Bishara, Covenants Not to Compete in a Knowledge Economy: Balancing Innovation from Employee Mobility against Legal Protection for Human Capital Investment, 27 Berkeley J. Emp. \& Lab. L. 287 (2006); Yuval Feldman, Experimental Approach to the Study of Normative Failures: Divulging of Trade Secrets by Silicon Valley Employees, 2003 U. ILl. J.L. TECH. \& Pol'y 105 (2003); Todd M. Foss, Comment, Texas, Covenants Not to Compete, and the Twenty-First Century: Can the Pieces Fit Together in a Dot.Com Business World?, 3 Hous. Bus. \& TAx L.J. 207 (2003); Joan T.A. Gabel \& Nancy R. Mansfield, The Information Revolution and its Impact on the Employment Relationship: An Analysis of the Cyberspace Workplace, 40 Am. Bus. L.J. 301 (2003); Thomas M. Hogan, Note, Uncertainty in the Employment Context: Which Types of Restrictive Covenants Are Enforceable?, 80 Sт. John's L. Rev. 429 (2006); John Dwight Ingram, Covenants Not to Compete, 36 Akron L. Rev. 49 (2002); Cristin T. Kist, Comment, Blocked Airwaves: Using Legislation to Make Non-Compete Clauses Unenforceable in the Broadcast Industry and the Potential Effects of Proposed Legislation in Pennsylvania, 13 Vill. Sports \& ENT. L.J. 391 (2006); Ted Lee \& Leila Ben Debba, Backdoor Non-Competes in Texas: Trade Secrets, 36 ST. MARY's L.J. 483 (2005); Louis J. Papa, Employee Beware! Employment Agreements and What the Technology Related Employee Should Know and Understand before Signing That Agreement: A Practical Guide, 19 Touro L. Rev. 393 (2003); Sela Stroud, Non-Compete Agreements: Weighing the Interests of Profession and Firm, 53 Ala. L. Rev. 1023 (2002); Jennifer Turner, Note and Comment, Noteboom: A Dramatic Deviation from Texas' Stand against Non-Competition Clauses among Lawyers, 58 BAYLOR L. REv. 1011 (2006); Kenneth J. Vanko, You're Fired! And Don't Forget Your Non-Compete ...": The Enforceability of Restrictive Covenants in Involuntary Discharge Cases, 1 DePaul Bus. \& Comm. L.J. 1 (2002); Mike J. Wyatt, Comment, Buy Out or Get Out: Why Covenants Not to Compete in Surgeon Employment Contracts are Truly Bad Medicine, 45 WASHBURN L.J. 715 (2006).

${ }^{24}$ The English common law prohibition dates back to 1414 and the famous Dyer's Case, Y.B. Mich. 2 Hen. 5, f. 5, pl. 26 (C.P. 1414). It has been noted that the original common law position was designed to prevent employers from circumventing the established customs of apprenticeship. Blake, supra note 23, at 632.

\footnotetext{
${ }^{25}$ United States v. Addyston Pipe \& Steel Co., 85 F. 271, 293 (6th Cir.), aff'd, 175 U.S. 211 (1898).

${ }^{26}$ For a discussion of the evolution of the common law reasonableness approach to employee noncompete agreements in the United States, see T. Leigh Anenson, The Role of Equity in Employment Noncompetition Cases, 42 Aм. Bus. L.J. 1, 9-14 (2005).
} 
interests in open and fair competition. Employers have a legitimate interest in preventing unfair competition through the misappropriation of business assets by former employees. ${ }^{27}$ On the other hand, employees have a countervailing interest in their own mobility and marketability. ${ }^{28}$ Society has interests in maintaining free and fair competition and in fostering a marketplace environment that encourages new ventures and innovation. ${ }^{29}$ There is a complementary public interest in preventing employers from using their superior bargaining position to unduly restrict labor markets. ${ }^{30}$ Given these competing interests, the common law approach allows employee noncompete agreements but imposes significant limits on restrictive covenants to assure that they are not overly burdensome to employees and harmful to the marketplace.

Under the common law approach, the employer must demonstrate a legitimate commercial reason for any agreement not to compete to ensure that the agreement is not a naked attempt to restrict free competition. Merely preventing competition from a former employee is not a sufficient justification for a noncompete agreement, even if the employee received training or acquired knowledge of a particular trade during his employment. ${ }^{31}$ Employees are entitled to use the general skills and knowledge acquired during their employment in competition with their former employer. ${ }^{32}$ An employer must demonstrate "special circumstances" that

\footnotetext{
${ }^{27}$ See Reed, Roberts Assocs, Inc. v. Strauman, 353 N.E.2d 590, 593 (N.Y. 1976) (noting the employer's "legitimate interest ... in safeguarding that which has made his business successful and to protect himself against deliberate surreptitious commercial piracy.”).
}

${ }^{28}$ See Standard Brands, Inc. v. Zumpe, 264 F. Supp. 254, 259 (E.D. La. 1967) ("[T]he employee himself must be afforded a reasonable opportunity to change jobs without abandoning the ability to practice his skills.").

${ }^{29}$ See Strauman, 353 N.E.2d at 593 ("[O]ur economy is premised on the competition engendered by the uninhibited flow of services, talent and ideas.").

${ }^{30}$ Blake, supra note 23 , at 650 .

${ }^{31}$ See, e.g., Club Aluminum Co. v. Young, 160 N.E. 804, 806 (Mass. 1928) (“[A]n employer cannot by contract prevent his employee from using the skill and intelligence acquired or increased and improved through experience or through instruction received in the course of the employment.").

${ }^{32}$ The Supreme Court of Illinois colorfully stated this policy as follows: "One who has worked in a particular field cannot be compelled to erase from his mind all of the general skills, knowledge and expertise acquired through his experience." ILG Indus., Inc. v. Scott, 273 N.E.2d 393, 396 (Ill. 1971). 
make the agreement necessary to prevent some form of unfair competition. ${ }^{33}$

Traditionally, the courts recognized two primary interests as legitimate justifications for a noncompete agreement: the employer's interests in protecting the goodwill of the business and in protecting its trade secrets. $^{34}$ An employee noncompete agreement is often designed to prevent an employee from taking advantage of the employer's goodwill, which the employee generated in his or her dealings with customers. ${ }^{35}$ Employees often develop personal relationships with their customers and clients, but the goodwill so generated is a valuable asset of the business because the employees are acting as agents at the time. ${ }^{36}$ Under the socalled "customer contact" theory, the relational interests of the former employer are protected. ${ }^{37}$

Protecting trade secrets is the second most common justification for employee restrictive covenants. Unlike the goodwill interest, however, the employer has an arsenal of legal weapons at its disposal to protect its trade secrets. Past employees are under a continuing fiduciary duty not to disclose or use trade secrets of their prior employers. ${ }^{38}$ Employers often supplement that common law protection with nondisclosure and confidentiality agreements specifying the proprietary business information that is to remain confidential. Employers can obtain injunctive relief to prevent the misappropriation of trade secrets or the imminent threat of such

\footnotetext{
${ }^{33}$ Whitmyer Brothers, Inc. v. Doyle, 274 A.2d 577, 582 (N.J. 1971) (quoting Vander Werf v. Zunica Realty Co., 208 N.E.2d 74, 76 (Ill. App. Ct. 1965)).

${ }^{34}$ Blake, supra note 23, at 653. See also Milton Handler \& Daniel E. Lazoroff, Restraint of Trade and the Restatement (Second) of Contracts, 57 N.Y.U. L. Rev. 669, 713-16 (1982).

${ }^{35}$ See Jordan Leibman \& Richard Nathan, The Enforceability of Post-Employment Noncompetition Agreements Formed After At-Will Employment Has Commenced: The "Afterthought Agreement," $60 \mathrm{~S}$. CAL. L. Rev. 1465, 1484-85 (1987).

${ }^{36}$ Blake, supra note 23 , at $654-55$.

${ }^{37}$ E.g., Lakeside Oil v. Slutsky, 98 N.W.2d 413, 415, 420 (Wis. 1959) (noting that the former employee's personal relationship with customers, whom the employee developed and served, enabled the former employee to take away the customers).

${ }^{38}$ See, e.g., Omega Optical, Inc. v. Chroma Tech. Corp., 800 A.2d 1064, 1066 (Vt. 2002) (noting the continuing duty of former employees not to disclose confidential information of the employer).
} 
improper use or disclosure. ${ }^{39}$ Moreover, in recent years, courts have increasingly protected trade secrets under the so-called inevitable disclosure doctrine. ${ }^{40}$ Under this theory, a court can prevent an employee from working for a competitor if the disclosure of trade secrets will be a virtual certainty given the knowledge base of the former employee and the position he or she has secured with the competitor. ${ }^{41}$

In the protection of trade secrets, noncompete agreements are used as a means of minimizing the potential for trade secret misappropriation by preventing an employee from working for a competitor or engaging in a competing enterprise. ${ }^{42}$ Also, restrictive covenants have practical value in that employers avoid the difficulties of proving an actual or threatened misappropriation of trade secrets to secure an injunction. ${ }^{43}$ This further allows employers to prevent any improper use of trade secrets before it occurs rather than responding to a misappropriation, when the harm (which may be significant) is done. ${ }^{44}$ Thus, employee noncompete agreements are designed as a preventative measure, effectively limiting the potential for trade secret disclosure or misappropriation by former employees.

If the employer establishes that a legitimate interest is served by an agreement not to compete, the terms of the noncompete agreement are examined to assure that it is no more extensive than necessary to serve that interest. This assessment considers the reasonableness of (1) the time period of the noncompete agreement, ${ }^{45}$ (2) the geographic area covered

\footnotetext{
${ }^{39}$ Unif. Trade Secret Act $§ 2$ (amended 1985), 14 U.L.A. 434 (1990). In addition, damages are a potential remedy for trade secret misappropriation. Id. $\S 3$.

${ }^{40}$ See infra Part VI.

${ }^{41}$ See, e.g., PepsiCo v. Redmond, 54 F.3d 1262, 1269 (7th Cir. 1995).

${ }^{42}$ Blake, supra note 23, at 670 .

${ }^{43}$ See, e.g., Comprehensive Techs. Int'l v. Software Artisans, 3 F.3d 730, 738-39 (finding no trade secret misappropriation but enforcing the employee noncompete agreement because secret information was at risk), vacated and appeal dismissed per stipulation, 1993 U.S. App. LEXIS 28601 (4th Cir. Sept. 30, 1993). See also Ronald J. Gilson, The Legal Infrastructure of High Technology Industrial Districts: Silicon Valley, Route 128, and Covenants Not to Compete, 74 N.Y.U. L. REv. 575, 597-600 (1999) (noting substantive and procedural limitations of protecting trade secrets under trade secret law).

${ }^{44}$ Blake, supra note 23 , at 669-70.

${ }^{45}$ In terms of time, courts tend to limit noncompete agreements to short durations, six months to one year being quite common and ordinarily within the range of reasonableness. See, e.g.,
} 
by it, ${ }^{46}$ and (3) the business activities restricted by the covenant. ${ }^{47}$ Because the scope of a noncompete agreement cannot be broader than reasonably necessary to protect the legitimate interests of the employer, courts applying the common law test are reluctant to allow noncompete agreements that prevent an employee from working in any position for a competitor or that prohibit an employee from engaging in a business that is not directly competitive with the former employer's business. In an oftcited opinion, the New York Court of Appeals upheld a noncompetition agreement that prevented an oral surgeon from engaging in the practice of oral surgery within a five-county area of New York, but it refused to enforce that part of the noncompete agreement that would have prevented the oral surgeon from practicing dentistry. ${ }^{48}$ The employer did not practice dentistry and thus the former employee would not be directly competing with him. ${ }^{49}$

Under the common law, courts were reluctant to partially enforce unreasonable postemployment restrictions. An overbroad agreement was either void per $\mathrm{se}^{50}$ or subject to severance under the "blue pencil"

Hopper v. All Pet Animal Clinic, Inc., 861 P.2d 531, 545-46 (Wyo. 1993) (time to hire new employee and give him or her reasonable opportunity to demonstrate effectiveness to customers who dealt with prior employee).

${ }^{46}$ See, e.g., Standard Register Co. v. Kerrigan, 119 S.E.2d 533, 539 (S.C. 1961) (“"T] $]$ he general rule [is] that the territorial restraint in a covenant not to compete will, generally speaking, be considered reasonable if the area covered by the restraint is limited to the territory in which the employee was able, during the term of his employment, to establish contact with his employer's customers."). It has been observed, however, that " $[\mathrm{m}]$ ost confidential information worthy of any protection at all is appropriately protectable without geographic limitation, because once an employee has divulged a trade secret in any location the likelihood that it will become public knowledge available to immediate competitors is greatly increased." Blake, supra note 23, at 679 .

${ }^{47}$ The type of activities that the noncompete agreement prohibits the employee from engaging in must be tied to the legitimate interests the employer is seeking to protect. See, e.g., Bridgestone/Firestone, Inc. v. Lockhart, 5 F. Supp. 2d 667, 683-84 (S.D. Ind. 1998) (finding the covenant overbroad because it limited former employee from working for competitor in any capacity and precluded him from selling products that were not directly competitive).

${ }^{48}$ Karpinski v. Ingrasci, 268 N.E.2d 751, 754-55 (1971).

${ }^{49} I d$.

${ }^{50}$ Georgia continues to follow the rule that an overbroad employee noncompete agreement cannot be severed under the "blue pencil" doctrine and such an agreement renders 
doctrine. ${ }^{51}$ Although the blue pencil doctrine allows courts to enforce separate lawful covenants within a contract or to strike language where a change is grammatically possible, it does not permit the courts to otherwise modify the terms of an agreement. ${ }^{52}$ The common law approach is supported by several policy arguments, the strongest being that to enforce an overbroad agreement by changing its terms encourages employers to draft onerous noncompete agreements to the potential detriment of employees. ${ }^{53} \mathrm{~A}$ related concern is that the courts should not rewrite a contract and impose it on an employee who did not voluntarily agree to it. $^{54}$

The probing examination of the terms of noncompete agreements under the common law approach, a form of strict judicial scrutiny, ${ }^{55}$ is reinforced by other rules that make it difficult to enforce postemployment restraints. The validity issue is considered a question of law to be determined by the courts, even though a consideration of the facts surrounding an agreement not to compete is essential for a determination of its enforceability. ${ }^{56}$ At the trial level, past employers who can demonstrate the reasonableness of the restraint must also establish the prerequisites for injunctive relief, particularly irreparable injury. ${ }^{57}$ On appeal,

unenforceable other noncompete or nonsolicitation covenants in the same agreement. E.g., Advanced Tech. Consultants, Inc. v. Roadtrac, L.L.C., 551 S.E.2d 735, 737 (Ga. App. 2001).

${ }^{51}$ See, e.g., Solari Indus. v. Malady, 264 A.2d 53, 55-57 (N.J. 1970) (discussing the void per se rule and the blue pencil doctrine and allowing reformation of an overbroad noncompete agreement to render it enforceable).

${ }^{52}$ See, e.g., Hartman v. W.H. Odell, 450 S.E.2d 912, 920 (N.C. App. 1994) (noting severe limits on the court's power to alter the contract under the blue pencil doctrine).

${ }^{53}$ Blake, supra note 23, at 682-83 (1960) ("If severance is generally applied, employers can fashion truly ominous covenants with confidence that they will be pared down and enforced when the facts of a particular case are not unreasonable. This smacks of having one's employee's cake, and eating it too.").

${ }^{54} S e e$, e.g., E. Bus. Forms v. Kistler, 189 S.E.2d 22, 24 (S.C. 1972) ("We cannot make a new agreement for the parties into which they did not voluntarily enter.").

${ }^{55}$ See, e.g., Gary Van Zeeland Talent, Inc. v. Sandas, 267 N.W.2d 242, 246-51 (Wis. 1978) (providing an in-depth review of the law regarding whether a customer list was a trade secret entitled to legal protection).

${ }^{56}$ E.g., Orkin Exterminating Co. v. Walker, 307 S.E.2d 914, 916 (Ga. 1983).

${ }^{57}$ For a recent discussion of the irreparable injury requirement in the employee noncompete agreement context, see the Alabama Supreme Court's opinion in Ormco Corp. v. Johns, 869 So. 
courts consider the question de novo, without the traditional deference accorded to trial court determinations on other issues. ${ }^{58}$ In effect, employee agreements not to compete come to the court with a heavy presumption of invalidity. The burden is on the employer to justify the need for and the reasonableness of the terms of the agreement.

\section{Restrictive State Statutes on Employee NONCOMPETE AGREEMENTS}

Traditionally, state restraint of trade statutes either prohibited employee agreements not to compete or severely restricted the circumstances under which such agreements could be enforced. Some states, notably California ${ }^{59}$ and North Dakota, ${ }^{60}$ continue to adhere to such restrictive laws. California's noncompete statute, Section 16600 of the California Business and Professions Code, which dates to 1872 , provides that "every contract by which anyone is restrained from engaging in a lawful profession, trade, or business of any kind is to that extent void." 61 This strong public policy favoring employee mobility has been vigorously protected by the California courts. Section 16600 has been interpreted to preclude any agreement that restricts an employee from working for a competitor of his former employer or imposing a penalty for doing so. ${ }^{62}$

California has recognized a limited trade secret exception to Section 16600 under which a noncompete agreement is permitted when it is necessary to protect a former employer's customer lists. An agreement preventing a former employee from using such confidential customer

2d 1109 (Ala. 2003). In a well-reasoned opinion, the Ormco court rejected the position of many courts that irreparable injury can be inferred from a mere breach of the noncompete agreement, opting instead for the position that only a rebuttable inference arises from such a breach. Id. at 1114-19.

${ }^{58}$ E.g., Bernier v. Merrill Air Eng'rs, 770 A.2d 97, 103 (Me. 2001).

${ }^{59}$ Cal. Bus. \& Prof. Code $§ 16600$ (West 1997).

${ }^{60}$ N.D. Cent. Code $\$ 9-08-06$ (2006). See text accompanying infra notes 222-31 for a discussion of the North Dakota Supreme Court's most recent opinion strictly interpreting Section 9-08-06.

${ }^{61}$ Cal. Bus. \& Prof. Code $§ 16600$.

${ }^{62}$ Muggill v. Reuben H. Donnelley Corp., 398 P.2d 147, 149 (Cal. 1965). 
information to solicit business was enforced by the California Supreme Court in Gordon v. Landau. ${ }^{63}$ The court reasoned that the agreement did not prevent the former employee from competing in violation of Section 16600. It only prevented him from using his former employer's valuable trade secrets in competition. ${ }^{64}$ Despite this exception, agreements not to compete in most employment settings are unenforceable in California. ${ }^{65}$

Regulatory statutes in other states limit the enforceability of employee noncompete agreements to a lesser extent than in California. ${ }^{66}$ Colorado, for example, refuses to enforce employee agreements not to compete other than restrictive covenants of high-level employees - executive and management personnel and officers and employees who constitute professional staff to executive and management personnel ${ }^{67}$ Consistent with the state's strong policy against covenants not to compete, ${ }^{68}$ this management

${ }^{63} 321$ P.2d 456 (Cal. 1958).

${ }^{64} I d$. at 459 .

${ }^{65}$ See, e.g., Metro Traffic Control, Inc. v. Shadow Traffic Network, 27 Cal. Rptr. 2d 573, 577 (Cal. Ct. App. 1994) (finding unenforceable under Section 16600 a noncompete agreement that prevented former employees from providing traffic reporting services for their former employer's customer, a radio station). The Metro Traffic court explained: "California courts have consistently declared [Section 16600] an expression of public policy to ensure that every citizen shall retain the right to pursue any lawful employment and enterprise of their choice." Id.

${ }^{66}$ Some states have general employee noncompete statutes that impose limits on postemployment restraints. For example, Alabama law provides as follows:

One who ... is employed as an agent, servant or employee may agree with his employer to refrain from carrying on or engaging in a similar business and from soliciting old customers of such employer within a specified county, city, or part thereof so long as the ... employer carries on a like business therein.

Ala. Code $§ 8-1-1$ (2002).

Other states have statutory provisions that address specific issues relating to employee noncompete agreements. Oregon requires independent consideration in the form of a "bona fide advancement" for a noncompete agreement entered after the commencement of employment to be binding. Or. Rev. Stat. Ann. § 653.295(1) (West Supp. 2006). Wisconsin codifies the common law reasonableness test, but it prevents a court from reforming or blue penciling an overbroad employee noncompete agreement. WIS. SтAт. § 103.465 (2004).

${ }^{67}$ Colo. Rev. Stat. Ann. § 8-2-113(2)(d) (West 2003).

${ }^{68}$ Dresser Indus., Inc. v. Sandvick, 732 F.2d 783, 787 (10th Cir. 1984) (recognizing the fundamental policy of Colorado disfavoring noncompete agreements in choice-of-law analysis). 
personnel exception has been construed narrowly by the Colorado courts. ${ }^{69}$ Thus, the exception has been limited to those who are in some sense "in charge" of a business. ${ }^{70}$ Under this view, account executives and other lower-level salespersons do not fall within the exception. ${ }^{71}$ Colorado also allows agreements necessary to protect trade secrets, but this exception has been given a similarly narrow reading by the courts. ${ }^{72}$

\section{THE MODERN APPROACH TO EMPLOYEE NONCOMPETE AGREEMENTS}

The traditional law of employee noncompete agreements was highly protective of the employee's interests in mobility and society's interest in free competition. Whether governed under the common law reasonableness test or under state restraint of trade statutes, employers had a demanding legal standard to meet in order to justify restrictions on postemployment competition. Gradually, however, many jurisdictions adopted less stringent approaches to such agreements. Some states adopted statutory provisions that liberalized the common law rules, thereby permitting employee noncompete agreements that would have been deemed unreasonable under traditional common law standards. Compared to the common law, this modern approach is more favorable to the interests of employers and less protective of the employee's interest in mobility.

\section{A. Broadening the Permissible Scope of Employee Noncompete Agreements}

Under the modern approach, courts have relaxed the common law reasonableness standard in terms of the permissible scope of employee

\footnotetext{
${ }^{69}$ See Gold Messenger, Inc. v. McGuay, 937 P.2d 907, 910 (Colo. App. 1997) (noting that exceptions are narrowly construed because noncompete agreements are disfavored in Colorado).

${ }^{70}$ Atmel Corp. v. Vitesse Semiconductor Corp., 30 P.3d 789, 794 (Colo. App. 2001).

${ }^{71}$ Mgmt. Recruiters of Boulder, Inc. v. Miller, 762 P.2d 763, 765 (Colo. App. 1988).

${ }^{72}$ See, e.g., Colorado Accounting Machs., Inc. v. Mergenthaler, 609 P.2d 1125, 1126 (Colo. App. 1980) ("Even if we assume, arguendo, that a narrowly drafted non-competition clause specifically protecting trade secrets would be a valid exception under [the statute], here, the sole purpose behind the restrictive covenant is to prohibit all competition.").
} 
noncompete agreements. Many courts employ a balancing-of-interests test that is more deferential to employers despite their stated adherence to the common law. ${ }^{73}$ Under the modern approach, restrictive covenants up to five years have been permitted by some courts. ${ }^{74}$ Covenants that are broader than necessary for the protection of the employer's interests have been upheld. Thus, for example, states taking a more relaxed approach have allowed noncompetition restrictions that protect more than just the customers with whom the employee had contacts. ${ }^{75}$ Similarly, a noncompete covenant preventing an employee from working in businesses that do not compete with the former employer's business has been upheld. ${ }^{76}$

The development of employee noncompete law in Ohio illustrates the shift from a strict common law reasonableness standard to the more relaxed modern approach to covenants not to compete in the employment context. ${ }^{77}$ In Ohio, the state courts initially followed a strict version of the common law reasonableness test. Thus, in the leading case of Briggs $v$.

\footnotetext{
${ }^{73}$ See, e.g., Dobbins, DeGuire \& Tucker v. Rutherford, 708 P.2d 577, 580 (Mont. 1985) (holding that the covenant should afford reasonable protection for-and not impose an unreasonable burden upon - the employer, the employee, or the public); Vermont Elec. Supply Co. v. Andrus, 315 A.2d 456, 458 (Vt. 1974) (mandating enforcement unless the agreement is contrary to public policy, unnecessary for protection of the employer, or unnecessarily restrictive of the employee's rights, considering the nature of the contract and circumstances of performance).

${ }^{74}$ See, e.g., Med. Educ. Assistance Corp. v. State, 19 S.W.3d 803, 816 (Tenn. Ct. App. 2000) (enforcing a five-year noncompete agreement between a medical school and a faculty physician, making special note of the important public interest in maintaining a viable medical school in upper east Tennessee).

${ }^{75}$ See, e.g., UZ Eng'red Prods. Co. v. Midwest Motor Supply Co., 770 N.E.2d 1068, 1080-81 (Ohio Ct. App. 2001).

${ }^{76} \mathrm{See}$ Roanoke Eng'g Sales Co. v. Rosenbaum, 290 S.E.2d 882, 885 (Va. 1982) (restriction on working for "similar" business).

${ }^{77}$ Kentucky is another state in which the courts have moved from the common law reasonableness approach to a more permissive standard for employee noncompete agreements. Compare Crowell v. Woodruff, 245 S.W.2d 447, 449 (Ky. App. 1951) (enforcing an employee noncompete agreement "where the purpose is to prevent unfair competition by the employee ... and the restraint is no greater than reasonably necessary to secure the protection") with Hammons v. Big Sandy Claims Svc., Inc., 567 S.W.2d 313, 315 (adopting the enforceability standard first applied in the sale-of-business context that a noncompete agreement is enforceable if "the restriction is such only as to afford fair protection to the interests of the covenantee and is not so large as to interfere with the public interests or impose undue hardship on the party restricted" (quoting Ceresia v. Mitchell, 242 S.W.2d 359, 364 (Ky. 1951))).
} 
Butler, ${ }^{78}$ the Ohio Supreme Court announced a rigorous, three-part standard to judge the enforceability of employee noncompete agreements. Postemployment restraints were enforceable only when: (1) the restriction was not "beyond that reasonably necessary for the protection of the employer in his business," (2) "the provisions [were] not unreasonably restrictive upon the rights of the employee," and (3) the covenant did "not contravene public policy.",79

Cases subsequent to Briggs continued to follow the common law approach. Thus, in Arthur Murray Dance Studios of Cleveland, Inc. v. Witter, ${ }^{80}$ the court rejected a dance studio's covenant that attempted to prevent one of its dance instructors from working for a competing dance studio. ${ }^{81}$ In a tour de force exposition on the law of employee noncompete agreements, the court first noted the heavy burden imposed on an employer to justify a "presumptively void" restrictive covenant. ${ }^{82}$ Such a restraint of trade should be "cautiously considered, carefully scrutinized, looked upon with disfavor, strictly interpreted and reluctantly upheld." 83 Applying the common law standards, the court concluded that Arthur Murray had not carried its burden to demonstrate the necessity for the postemployment restraint, either under the "customer contact" or trade secret theories. ${ }^{84}$ It found that the employee did not have the requisite "hold" over the dance studio's customers and the training in the Arthur Murray teaching methods was not a trade secret. ${ }^{85}$

Similarly, in Extine v. Williams Midwest, Inc. ${ }^{86}$ the Ohio Supreme Court followed the common law blue pencil rule in severing portions of an overbroad noncompete agreement. ${ }^{87}$ Although the court noted a trend in

\footnotetext{
7845 N.E.2d 757 (1942).

${ }^{79} I d$. at 763 .

${ }^{80} 105$ N.E.2d 685 (Ohio C.P. Ct. 1952).

${ }^{81} I d$. at 711-12.

${ }^{82} I d$. at 693.

${ }^{83} \mathrm{Id}$.

${ }^{84} I d$. at $705-11$.

${ }^{85} I d$. at 709 .

${ }^{86} 200$ N.E.2d 297 (1964).

${ }^{87} I d$. at $299-300$.
} 
the law permitting reformation of overbroad restrictive covenants, it adhered to the traditional rule, in part because it had implicitly approved that rule in Briggs. ${ }^{88}$ However, Extine was overruled eleven years later in the landmark case of Raimonde $v$. Van Vlerah, ${ }^{89}$ a case that began a more permissive approach to employee noncompete agreements in the state. In discarding the blue pencil doctrine and granting courts broad power to modify noncompete agreements, the court signaled a new direction. ${ }^{90}$ Its policy justifications in favor of the move to reformation reflected a proemployer view of postemployment restraints. ${ }^{91}$ Also, it rejected the argument that allowing courts to reform unreasonable noncompete agreements would encourage employers to impose overbroad restraints on employees. ${ }^{92}$ Thus, both the tenor and result of the court's opinion deviated from the common law suspicion of restraints of trade in the employment context.

The Raimonde court's more relaxed approach to postemployment restraint agreements was substantially reinforced by the court's subsequent opinion in Rogers $v$. Runfola $\mathcal{E}^{3}$ Associates, Inc ${ }^{93}$ In Raimonde, the court had announced a list of factors to consider in determining the reasonable scope of an employee noncompete agreement. ${ }^{94}$ In Runfola, the court in effect created a balancing-of-interest standard for employee noncompete agree-

${ }^{88} I d$. at $298-99$.

${ }^{89} 325$ N.E.2d 544 (Ohio 1975).

${ }^{90} I d$. at 546 .

${ }^{91} I d$. ("Because employers seek to ensure that provisions are not unreasonable, and therefore severed, employees may gain the benefit of overly-lenient employment restrictions.”).

${ }^{92} I d$. at 547 ("Most employers who enter contracts do so in good faith, and seek only to protect legitimate interests. In fact, relatively few employment contracts reach the courts.’).

${ }^{93} 565$ N.E.2d 540 (Ohio 1991).

${ }^{94}$ The Raimonde court stated:

Among the factors properly to be considered are: "[t]he absence or presence of limitations as to time and space, ... whether the employee represents the sole contact with the customer; whether the employee is possessed with confidential information or trade secrets; whether the covenant seeks to eliminate competition which would be unfair to the employer or merely seeks to eliminate ordinary competition; whether the covenant seeks to stifle the inherent skill and experience of the employee; whether the benefit to the employer is disproportional to the detriment to the employee; whether the covenant operates as a bar to the employee's sole means of support; whether the employee's talent which the employer seeks to suppress was actually developed during 
ments, ${ }^{95}$ one that relies heavily on the "Raimonde factors" as they have become known in Ohio. ${ }^{96}$

Runfola involved a two-year noncompete agreement executed by two former employees of Runfola \& Associates, a court reporting service. The employees, who had attended school to become court reporters, were prohibited from engaging in court reporting services within Franklin County, in which Columbus is located. The agreement also contained an antisolicitation and antipiracy provision that had no time limit. After leaving the firm, the employees sought and secured a declaratory judgment that their noncompete agreements were unenforceable and then commenced a court reporting service within the county. ${ }^{97}$

The Ohio Supreme Court found the noncompete agreements to be unreasonable, both temporally and geographically, particularly in light of the unique nature of court reporting services. ${ }^{98}$ Nevertheless, the court enforced the agreement for one year, prohibiting both competition and solicitation of Runfola's clients within Columbus. ${ }^{99}$ In doing so, the court found that Runfola \& Associates had a legitimate business justification for the noncompete agreements in the general training it provided the court reporters. ${ }^{100}$

No doubt any employer can argue that it helped develop the talent of an employee by providing valuable experiences in the field. But under the common law reasonableness standard, this type of generalized skill and training is not ordinarily considered sufficient to justify a postemployment

the period of employment; and whether the forbidden employment is merely incidental to the main employment."

Raimonde, 325 N.E.2d at 547 (quoting Extine, 200 N.E.2d at 406).

${ }^{95}$ Runfola, 565 N.E.2d at 543.

${ }^{96}$ See, e.g., Procter \& Gamble Co. v. Stoneham, 747 N.E.2d 268, 270 (Ohio App. 2000) (listing factors and referring to them as the "Raimonde factors").

${ }^{97}$ Runfola, 565 N.E.2d at 541-42.

${ }^{98} I d$. at 544 .

${ }^{99} I d$.

${ }^{100} I d$. ("Runfola played a large role in [the employees'] development as successful court reporters. While employed by Runfola, Rogers and Marrone gained valuable experience in the business ... Much of this training and support, undoubtedly, inured to the benefit of the [employees]."). 
restraint. ${ }^{101}$ Although extraordinary training provided by employers has been deemed sufficient by some courts, ${ }^{102}$ in Runfola it was the employees themselves who secured the specialized education and training necessary to practice court reporting. ${ }^{103}$ Thus, Runfola expands the business interests that employers can protect under covenants not to compete and thereby broadens the permissible scope of such agreements. The combined effect of Raimonde and Runfola is to significantly liberalize the law of employee noncompete agreements in Ohio. Under the multifactor balancing-of-interests standard that has been adopted in the state, broad employee noncompete agreements are enforceable. $^{104}$

\section{B. Expanding the Interests Protectable under Employee Noncompete Agreements}

Under the modern approach, many jurisdictions also have liberalized the common law standards by broadening the interests that legitimately can be protected by employee noncompete agreements. Some courts have indicated that the employer's informational interest extends beyond the trade secret category to other business information. ${ }^{105}$ Thus, in Ingersoll-Rand v. Ciavatti ${ }^{106}$ the New Jersey Supreme Court held that an employer has a legitimate interest in protecting "highly specialized, current information not generally known in the industry, created and stimulated by the research environment furnished by the employer, to which the employee has been 'exposed' and 'enriched' solely due to his

\footnotetext{
${ }^{101}$ Blake, supra note 23, at 652 ("It has been uniformly held that general knowledge, skill or facility acquired through training or experience while working for an employer appertain exclusively to the employee. The fact that they were acquired or developed during the employment does not, by itself, give the employer a sufficient interest to support a restraining covenant. ... "). See also supra notes 31-32 and accompanying text.

${ }^{102}$ See infra notes $109-11$ and accompanying text.

${ }^{103} 565$ N.E.2d at 544.

${ }^{104}$ See, e.g., UZ Eng'red Prods. Co. v. Midwest Motor Supply Co., 770 N.E.2d 1068, 1081 (Ohio Ct. App. 2001) (upholding a noncompete agreement that protected the entire existing and potential customer base of the former employer).

${ }^{105}$ E.g., L.M. Saliterman and Assocs. v. Finney, 361 N.W.2d 175, 178 (Minn. App. 1985) (citing Cherne Indus., Inc. v. Grounds \& Assocs., 278 N.W.2d 81, 92 (Minn. 1979) (holding that an injunction may be appropriate to protect confidential information even if the information is not a trade secret).
}

${ }^{106} 542$ A.2d 879 (N.J. 1988). 
employment." 107 The Ciavatti court carefully limited this business interest to a narrow category of research-and-development (R\&D) - generated information, which one could arguably claim is protected under trade secret law. ${ }^{108}$ To that extent, Ciavatti's outcome does not run contrary to well-settled employee noncompete law. However, the extension to business information that is not protected under trade secret law is inconsistent with the principle that an employer has no legitimate interest in preventing a past employee from using his or her general skills and knowledge in competition. Moreover, because noncompete agreements are justified as a preventative measure in the trade secret context, it is difficult to argue that a noncompete agreement is necessary to protect information that is either not secret or that does not give the firm a competitive advantage in the market. An employee using such information is certainly engaged in competitive activity, but not in the type of unfair competition that noncompete agreements are designed to prevent. Nevertheless, modern decisions like Ciavatti, if not carefully circumscribed by the courts, have the potential to significantly expand the circumstances under which an employer can conceivably justify an employee noncompete agreement.

A similar expansion has occurred in the area of employee education and training. Traditionally, courts recognized a legitimate interest in employee education costs that are extraordinary or involve specialized training. ${ }^{109}$ The idea underlying the extraordinary training interest is that if an employer has expended substantial resources to provide an employee with some unique skills, then it would be unfair for that employee to use those skills to compete with his former employer. ${ }^{110}$ A less restrictive alternative to the employer's interest in employee training expenses is the approach adopted in Colorado. By statute, Colorado law allows a

\footnotetext{
${ }^{107} I d$. at 894 .

${ }^{108} I d$.

${ }^{109}$ See, e.g., Robbins v. Finlay, 645 P.2d 623, 627 (Utah 1982) (commenting that "an extraordinary investment in the training or education of the employee" is a protectable interest); Voorhees v. Guyan Mach. Co., 446 S.E.2d 672, 677 (W. Va. 1994).

${ }^{110}$ Hapney v. Cent. Garage, Inc., 579 So. 2d 127, 132 (Fla. App. 1991) ("The rationale is that if an employer dedicates time and money to the extraordinary training and education of an employee, whereby the employee attains a unique skill or an enhanced degree of sophistication in an existing skill, then it is unfair to permit that employee to use those skills to the benefit of a competitor when the employee has contracted not to do so.").
} 
contractual provision for the recovery of the expense of educating and training an employee who has served an employer for a period of less than two years. ${ }^{111}$

Despite these limitations and alternatives, some courts have expanded this interest to include generalized training, enforcing employee noncompete agreements where the employee has acquired no unique or specialized skills. ${ }^{112}$ Thus, in Borg-Warner Protective Services, Corp. v. Guardsmark, Inc., ${ }^{113}$ the court enforced a noncompete agreement as it applied to security guards who were hired away by a rival private security firm (BorgWarner). In upholding the covenant, the court did not rely on any employer interest in trade secrets or goodwill, because the security guards were not privy to any trade secrets nor did they have any close relationships with any of Guardsmark's customers. ${ }^{114}$ The court concluded that Guardsmark had a legitimate interest in its investment in the guards, noting the two-week, on-the-job training and their education in the "culture of the client's firm and the client's own security personnel."115 Although the court may have been able to reconcile its decision with the traditional common law approach, ${ }^{116}$ it chose to take an expansive view of the interests protectable under employee noncompete agreements. Recognizing investment in generalized employee training as a legitimate interest is a clear departure from the common law, one that substantially broadens the situations under which employee noncompete agreements will be enforced.

\footnotetext{
${ }^{111}$ Colo. Rev. Stat. Ann. § 8-2-113(2)(c) (West 2003). For an insightful discussion of training repayment agreements, see generally Brandon S. Long, Note, Protecting Employer Investment in Training: Noncompetes vs. Repayment Agreements, 54 Duke L.J. 1295 (2005).

${ }^{112}$ See, e.g., Rogers v. Runfola \& Assocs., Inc., 565 N.E.2d 540 (Ohio 1991). See supra notes 93104 and accompanying text (discussing Runfola case).

${ }^{113} 946$ F. Supp. 495 (E.D. Ky. 1996).

${ }^{114} I d$. at 501 (noting that the common law would not enforce covenants against employees whose services were not unique (absent trade secrets or customer relationships), but reasoning that "the more modern cases, including those in Kentucky, place more emphasis on the employer's investment in the employee and have evolved an approach balancing the importance of that factor against the hardship to the employee and the public interest").

${ }^{115} I d$. at 502 .

${ }^{116}$ It could be argued that the employees received a form of specialized training because they learned the unique security features of the client's security system.
} 


\section{The Movement From the Blue Pencil Doctrine to Reformation}

Many states also grant the courts broad power to modify or change the terms of an overbroad employee noncompete agreement so as to render the agreement enforceable. ${ }^{117}$ Although some states continue to reject partial enforcement of any kind ${ }^{118}$ or limit the courts' power to rewrite the terms of a restrictive covenant based on common law contract principles, ${ }^{119}$ there has been a clear shift from the blue pencil doctrine to reformation. ${ }^{120}$ Reformation allows the courts to modify an agreement not to compete (even if the agreement is not divisible into separate covenants) and to enforce the agreement as reformed. ${ }^{121}$ Proponents of reformation have criticized the common law approach as being too "mechanical," placing undue emphasis on whether covenants are separate and thereby glorifying form over substance. ${ }^{122}$ A related argument is that reformation allows the courts the discretion to fashion reasonable terms that are consistent with the general intent of the parties to enter into a binding noncompete agreement. ${ }^{123}$ The policy concern about overreaching by employers is resolved by refusing to permit reformation where employers have deliberately drafted unreason-

\footnotetext{
${ }^{117}$ This is considered the majority rule. Data Mgmt., Inc. v. Greene, 757 P.2d 62, 64 (Alaska 1988). See also Restatement (Second) of Contracts $\$ 184$ (1981) (adopting the rule of reformation).

${ }^{118}$ By statute, Wisconsin voids any overbroad agreement not to compete. Wis. STAT. $§ 103.465$ (2004).

${ }^{119}$ E.g., Hartman v. Odell \& Assocs., Inc., 450 S.E.2d 912, 920 (N.C. App. 1994) (holding that the court cannot erase and replace offending terms of a noncompete agreement); E. Bus. Forms, Inc. v. Kistler, 189 S.E.2d 22, 24 (S.C. 1972) ("We must uphold the covenant as written or not at all, it must stand or fall integrally.").

${ }^{120}$ State statutes in Florida, Michigan, and Texas specifically empower courts to reform unreasonable employee agreements not to compete. Fla. Stat. Ann. § 542.335(1)(c) (West 2002); Мich. Comp. Laws Ann. § 445.774a (West 2002); Tex. Bus. \& Com. Code Ann. § 15.51(c) (Vernon 2002).

${ }^{121}$ See, e.g., BDO Seidman v. Hirshberg, 712 N.E.2d 1220, 1226-27 (N.Y. 1999) (endorsing the reformation approach by enforcing only part of a single, nondivisible paragraph of the covenant).

${ }^{122}$ See, e.g., Data Mgmt., 757 P.2d at 64.

${ }^{123}$ See, e.g., Raimonde v. Van Vlerah, 325 N.E.2d 544, 547 (Ohio 1975) ("It permits courts to fashion a contract reasonable between the parties, in accord with their intention at the time of contracting, and enables them to evaluate all the factors comprising 'reasonableness' in the context of employee covenants.").
} 
able provisions. ${ }^{124}$ A court may refuse to reform an overbroad noncompetition agreement if it finds that the employer did not act in good faith; ${ }^{125}$ however, there are a few cases in which the courts have invalidated a noncompete agreement on this basis, because the good faith standard is ill defined and "bad faith" is a difficult standard to prove. ${ }^{126}$

\section{Liberalizing the Interpretation of Restrictive Restraint of Trade Statutes}

Several jurisdictions have broadened the permissible scope of employee noncompete agreements by reinterpreting seemingly restrictive restraint of trade statutes to allow noncompete agreements that would otherwise be invalidated under the traditional reading of the statutory language. Oklahoma and Montana both adopted the same restraint of trade statute that exists in California and North Dakota. ${ }^{127}$ Originally, courts in both states adopted an interpretation consistent with California's, which prohibited agreements that directly or indirectly restrict an employee's right to exercise a lawful trade, business, or profession. ${ }^{128}$ Nevertheless, both jurisdictions subsequently adopted a more permissive approach to employee noncompete agreements, abandoning the California approach for one that permits postemployment restrictions under a common law reasonableness formulation. ${ }^{129}$

In J.T. Miller Co. v. Madel, ${ }^{130}$ the Montana Supreme Court invalidated a noncompete agreement that prohibited a former field agent of a life

\footnotetext{
${ }^{124}$ See, e.g., Cent. Adjustment Bureau, Inc. v. Ingram, 678 S.W.2d 28, 37 (Tenn. 1984) ("If there is credible evidence to sustain a finding that a contract is deliberately unreasonable and oppressive, then the covenant is invalid.").
}

${ }^{125}$ See Restatement (Second) of Contracts $§ 184$ (1), (2) (1981) (reformation permitted "if party who seeks to enforce the term obtained it in good faith and in accordance with reasonable standards of fair dealing").

${ }^{126}$ But see, e.g., Smith, Batchelder \& Rugg v. Foster, 406 A.2d 1310, 1313-14 (N.H. 1979) (finding a lack of good faith because the noncompete covenants were not discussed during negotiations and employees did not have a full understanding of the restrictions).

${ }^{127}$ Compare Mont. Code Ann. § 28-2-703 (2005); OкLa. Stat. tit. 79, § 217 (2007) with Cal. Bus. \& Prof. Code $§ 16600$ (West 1997); N.D. Cent. Code § 9-08-06 (2006).

${ }^{128}$ J.T Miller Co. v. Madel, 575 P.2d 1321, 1323 (Mont. 1978); E.S. Miller Labs., Inc. v. Griffin, 194 P.2d 877, 1879 (Okla. 1948).

${ }^{129}$ Dobbins, DeGuire \& Tucker, P.C. v. Rutherford, MacDonald \& Olson, 708 P.2d 577, 580 (Mont. 1985); Bayly, Martin \& Fay, Inc. v. Pickard, 780 P.2d 1168, 1170 (Okla. 1989).

${ }^{130} 575$ P.2d 1321 (Mont. 1978). 
insurance company from engaging in the sale of insurance for five years. ${ }^{131}$ Relying on the California interpretation of the statutory language, ${ }^{132}$ the Madel court rejected the argument advanced by the employer that the prohibition on trade restraints was not absolute but rather permitted reasonable covenants not to compete. ${ }^{133}$ Consequently, the employee was free to compete and use his general experience and knowledge in competition. ${ }^{134}$ The restraint of trade statute prohibited any agreement that restricted that right. ${ }^{135}$

But, in 1985, the Montana Supreme Court reinterpreted the statute and created a permissive balancing test to judge the enforceability of employee noncompete agreements. In Dobbins, DeGuire E Tucker, P.C. v. Rutherford, MacDonald $\mathcal{E}^{\circ}$ Olson, ${ }^{136}$ the noncompete agreement required the employee, an accountant, to make substantial payments to his former employer in the event that the accountant left his position and continued to work with prior firm clients. ${ }^{137}$ Instead of following Madel, the court in Dobbins distinguished the facts in Madel from those in Dobbins. While in Madel the noncompete directly restricted the employee's right to engage in a competing business, in Dobbins the noncompete did so only indirectly by imposing an economic sanction for any breach of its terms. ${ }^{138}$ Using that factual distinction, the Dobbins court effectively changed the settled interpretation of the statute, reasoning that the law's prohibitory language was limited to situations where there was an absolute prohibition on an employee's right to engage in a profession. ${ }^{139}$

The court concluded that, in the absence of such a complete restraint, the statute did not necessarily invalidate a noncompete agreement in an employment setting. It adopted a three-part test to determine the validity

\footnotetext{
${ }^{131} I d$. at 1322 .

${ }^{132} I d$.

${ }^{133} I d$. at 1323.

${ }^{134} I d$. at $1323-24$.

${ }^{135} I d$. at 1323 .

${ }^{136} 708$ P.2d 577 (Mont. 1985).

${ }^{137} I d$. at 578 .

${ }^{138} I d$. at 579.

${ }^{139} I d$.
} 
of employee noncompete agreements. ${ }^{140}$ The test is permissive in that it requires courts to balance "the competing interests of the public as well as the employer and employee." ${ }^{141}$ Madel was effectively (but silently) overruled.

\section{E. The Adoption of Permissive State Statutes}

A number of jurisdictions have adopted employee noncompete statutes that expand the circumstances under which noncompete agreements would be allowed under the common law reasonableness approach ${ }^{142}$ or that liberalize the rules under existing restraint of trade statutes. ${ }^{143}$ One of

\footnotetext{
${ }^{140} I d$. at 580 (“(1)The covenant should be limited in operation either as to time or place; (2) the covenant should be based in some good consideration; and (3) the covenant should afford a reasonable protection for and not impose an unreasonable burden upon the employer, the employee or the public.").
}

${ }^{141} I d$.

${ }^{142}$ See, e.g., Am. Rim \& Brake, Inc. v. Zoellner, 382 N.W.2d 421, 424 (S.D. 1986) (finding noncompete agreements permissible under statute without requiring an independent showing of reasonableness).

${ }^{143}$ Michigan also adopted a liberalizing statute in 1985, the Michigan Antitrust Reform Act (MARA). Мich. Comp. Laws § 445.774a (2002). Prior to the passage of MARA, Michigan law prohibited almost every form of employee agreement not to compete. See Frank T. Mamat, $A n$ Overview of Employment Agreements-Covenants Not to Compete and Arbitration Agreements, $76 \mathrm{MicH}$. B.J. 1090, 1090 (1997). MARA parallels the common law reasonableness approach to employee noncompete agreements. For a discussion of the history of noncompete law in Michigan, see Bristol Window and Door, Inc. v. Hoogenstyn, 650 N.W.2d 670, 674-80 (Mich. App. 2002).

With the passage of the Texas Covenants Not to Compete Act, Tex. Bus. \& Com. Code Ann. $\S \S 15.50-52$ (Vernon 2002), Texas is another state that attempted by statute to liberalize the rules relating to employee agreements not to compete. However, the Act has been given a narrow interpretation by the Texas Supreme Court. In Light v. Centel Cellular Co., 883 S.W.2d 642, 647 (Tex. 1994), the court held that a noncompete covenant can be based on an at-will relationship only if a twofold consideration requirement is met. First, the consideration given by the employer in the agreement must give rise to the employer's interest in restraining the employee from competing. Id. at $647 \mathrm{n} .14$. Second, the restrictive covenant must be designed to enforce the employee's consideration or return promise in the agreement. Id. Thus, if an employee is given proprietary business information, agrees not to disclose that information, and signs an agreement not to compete, the restrictive covenant is ancillary to that nondisclosure agreement. If, on the other hand, an at-will employee who has already been given access to trade secrets is requested to sign a restrictive covenant, it is probably not ancillary to any otherwise enforceable agreement. In its most recent decision, Alex Sheshunoff Management Services v. Johnson, 209 S.W.3d 644 (Tex. 2006), the Texas Supreme Court did not abandon the test under Light, but the court allowed an employer's promise of future performance (such as a promise to provide the employee with confidential information), to be sufficient consideration for a covenant not to compete. Id. at 662 . 
the most extreme examples is the Florida restrictive covenants law passed in $1996 .{ }^{144}$ The statute contains a nonexclusive laundry list of protectable interests, which not only includes the traditional interests in trade secrets and customer relationships, but also extends to interests in an ongoing business or professional practice, professional information that otherwise does not qualify as trade secrets, relationships with prospective customers, and extraordinary specialized training. ${ }^{145}$ Although the courts must consider the reasonableness of the noncompete covenant in terms of scope, the statute conflicts with the common law approach in other respects. First, rather than giving restrictive covenants a strict construction, covenants are to be construed in favor of providing reasonable protection to all legitimate business interests of the employer. ${ }^{146}$ Second, once the employer establishes a legitimate business interest to be served by the covenant, the burden shifts to the employee to demonstrate the unreasonableness of the agreement, a reversal of the burden imposed under the common law. ${ }^{147}$ Finally, courts are specifically empowered to grant any appropriate and effective remedy, including to award attorney fees to the prevailing party and to reform an overbroad noncompete agreement. ${ }^{148}$ It is fair to say that the statute adopts an approach to employee noncompete agreements that is extremely favorable to business interests in the state, one that runs counter to the common law reasonableness test. ${ }^{149}$

\section{F. Summary}

Considered in isolation, the modern changes to the law of employee noncompete agreements could be viewed as minor deviations from the

\footnotetext{
The Texas legislature's attempt to liberalize the law of employee noncompete agreements has only been partially successful.

${ }^{144}$ Fla. Stat. Ann. $\$ 542.335$ (West 2002).

${ }^{145} I d . \S 542.335(1)(\mathrm{b})$.

${ }^{146} I d . \S(1)(\mathrm{h})$.

${ }^{147} I d . \S(1)(\mathrm{c})$.

${ }^{148} I d . \S(1)(\mathrm{j})$.

${ }^{149}$ See, e.g., Balasco v. Gulf Auto Holding, 707 So. 2d 858, 860 (Fla. Ct. App. 1998) (upholding a nonpiracy agreement in an automobile salesperson's contract and recognizing a legitimate interest in "promoting productivity and maintaining a competent and specialized sales team").
} 
traditional approach to the enforceability of postemployment restraints. Taken together, however, these changes have substantially altered the legal landscape for employees bound by covenants not to compete. The modern approach represents a liberalization of both the common law and statutory rules relating to employee noncompete agreements. Employers can more easily justify and enforce such agreements under the modern approach. In addition, employers have discretion to impose broad, standardized noncompete agreements on employees, knowing that the courts will generally reform their agreements if they are deemed unreasonable. Coupled with these changes are other tools to prevent competition by former employees, including the threat of suits for intentional interference with contracts against employers hiring employees subject to noncompete covenants. ${ }^{150}$ While the balance of competing interests at common law was tilted toward the employee's interests in mobility, and society's interests in free competition, the modern approach shifts the balance toward the employer's interests in protecting its property and forestalling competition by former employees.

\section{The Emerging Law: Heightened Scrutiny of EMPLOYEE NONCOMPETE AGREEMENTS}

An analysis of the most recent court opinions on employee noncompete agreements reveals a new trend. Our review of significant state supreme court decisions from 1999 to 2006 and other legal developments related to the law of employee noncompete agreements indicates a heightened judicial scrutiny of employee noncompete agreements. This new trend is clearly a retreat from the permissive modern approach and a movement back to the restrictive doctrines of the common law.

\section{A. Limiting the Business Interests Protectable Under Noncompete Covenants}

One facet of the recent trend can be seen in the courts' approach to the threshold issue of a protectable interest. Courts in recent opinions have carefully limited the types of business interests that can justify the imposi-

\footnotetext{
${ }^{150}$ See, e.g., Kallok v. Medtronic, Inc., 573 N.W.2d 356, 361-62 (Minn. 1998) (recognizing a cause of action for tortious interference with a valid employment noncompete agreement).
} 
tion of postemployment restraints. ${ }^{151}$ By narrowly defining the interests protectable under employee noncompete agreements, the most recent opinions reject the expansion of such interests under the modern approach.

The New York Court of Appeals, in BDO Seidman v. Hirshberg, ${ }^{152}$ clarified the extent to which the employer's interest in goodwill could justify a noncompete agreement. The Court of Appeals had traditionally recognized an interest in customer relationships, protecting employers from competition by former employees whose skills or services were unique or extraordinary. ${ }^{153}$ Members of medical and other professions generally had been considered to provide unique or extraordinary services and were potentially subject to broader restrictions than other employees. $^{154}$

In BDO Seidman, the Court of Appeals declined to extend that general rule to all professional employees. ${ }^{155}$ The case involved a manager of BDO Seidman, a public accounting firm. Jeffrey Hirshberg worked for BDO Seidman for five years when he was promoted to the level of manager, a step below partner. As a condition of the advancement, he signed a manager agreement that contained a provision requiring him to pay liquidated damages if he served any former client of BDO within eighteen months of his termination. He later left the firm and allegedly served some of BDO's clients in breach of the manager contract. ${ }^{156}$

On appeal, the Court of Appeals conceded that accounting has all of the characteristics of a learned profession, but it refused to follow the learned profession cases. ${ }^{157}$ Instead, the court concluded that Hirshberg's

\footnotetext{
${ }^{151}$ E.g., Nat'l Employment Serv. Corp. v. Olsten Staffing Serv., Inc., 761 A.2d 401, 405 (N.H. 2000) (costs associated with recruiting and hiring employees are not a legitimate interest for an employee noncompete agreement).

${ }^{152} 712$ N.E.2d 1220 (N.Y. 1999).

${ }^{153}$ Reed, Roberts Assocs., Inc. v. Strauman, 353 N.E.2d 590, 593 (N.Y 1976).

${ }^{154}$ See, e.g., Lumex v. Highsmith, 919 F. Supp. 624, 633 (E.D.N.Y. 1996); Strauman, 353 N.E.2d at 593 (noting the application of unique or extraordinary skills or services standard to members of the learned professions).

${ }^{155} 712$ N.E.2d at 1226.

${ }^{156} I d$. at 1221 .

${ }^{157} I d$. at 1223-24 (noting accountancy "has all the earmarks of a learned profession," including the "extensive formal training and education" of CPAs, the requirement that CPAs
} 
status in the firm was not based upon the uniqueness or extraordinary nature of the accounting services he generally performed on behalf of the firm, but mostly on his ability to attract a corporate clientele. ${ }^{158}$ As a result, the court carefully scrutinized the legitimacy of any interest claimed by BDO under the common law standard. ${ }^{159} \mathrm{BDO}$ contended that it was entitled to protect its entire client base because a modern accounting firm spends considerable resources to build and maintain that base. ${ }^{160}$ The court found only an interest in protecting the client base from unfair competition. Unless a former employee uses confidential information to obtain clients, the employer's interest is limited to the client relationships that the employer enabled the employee to acquire in the performance of his work. The noncompete agreement was fatally overbroad to the extent that it applied to clients with whom Hirshberg had no significant relationship while at $\mathrm{BDO}$ as well as clients who employed $\mathrm{BDO}$ as a result of Hirshberg's independent recruitment efforts. $^{161}$

$B D O$ Seidman circumscribes the legitimate interests that an employer can claim to justify a noncompete agreement, tying the goodwill interest to client and customer relationships acquired by the employee in the course of his employment. The court also limited the application of prior opinions that suggested that all professional employees would be characterized as having unique or extraordinary skills. After BDO Seidman, that category of employee will be limited to employees whose peculiar skills give them a unique competitive advantage over their former employer.

B. Restricting the Scope of Employee Noncompete Agreements and Limiting the Power of Reformation

Another aspect of the trend of recent opinions heightening the judicial scrutiny of employee noncompete agreements has been the adoption of

pass a written examination, CPAs' continuing education requirements, the oversight of a professional standards board governed by statutory disciplinary procedures, and the existence of a national code of professional conduct).

\footnotetext{
${ }^{158} I d$. at 1224.

${ }^{159} I d$. at $1224-26$.

${ }^{160} I d$. at 1224.

${ }^{161} I d$. at 1225 .
} 
rules narrowing the enforceable scope of such agreements. ${ }^{162}$ Complementing these restrictive doctrines has been a shift in judicial thinking regarding the modern rule permitting the reformation of an overbroad noncompete covenant. The trend has been to limit the courts' power to reform the parties' agreement, either by following the traditional blue pencil doctrine or by placing significant limits on the reformation power. We discuss examples of each below. As a result of these developments, the permissible scope of noncompete agreements has been substantially curtailed in recent opinions.

In a landmark opinion, the Arizona Supreme Court held in Valley Medical Specialists $v$. Farber ${ }^{163}$ that a noncompete clause under a shareholder/employment agreement, which restricted a physician's medical

${ }^{162}$ In Mertz v. Pharmacists Mut. Ins. Co., 625 N.W.2d 197, 204-06 (Neb. 2001), the Nebraska Supreme Court invalidated an employee noncompete agreement that prohibited a former employee from soliciting pharmacists in the entire state of Nebraska regardless of the pharmacists' relationship to the employer or former employee. In doing so, the Mertz court clarified an apparent conflict in its prior opinions on the permissable scope of employee noncompete agreements. In Polly v. Ray D. Hilderman छ Co., 407 N.W.2d 751, 756 (Neb. 1987), the Nebraska Supreme Court had announced as a general rule that a covenant not to compete in an employment contract may be valid only if it restricts the former employee from soliciting the former employer's clients or accounts with whom the former employee actually did business and had personal contact. But in a prior opinion, Dana F. Cole \& Co. v. Byerly, 320 N.W.2d 916, 918 (Neb. 1982), the court had approved a restrictive covenant preventing a manager of an accounting firm from doing accounting work within seventy-five miles of the branch office he managed. The Mertz court explicitly overruled Dana F. Cole and thereby restricted the permissible breadth of employee noncompete agreements. Mertz, 625 N.W. 2d at 205.

In a surprising series of recent opinions, the Virginia Supreme Court, which had embraced the modern approach, adopted restrictive standards for employee noncompete agreements. Virginia had allowed covenants restricting employees from directly or indirectly engaging in any employment or competition with their former employer, in the same or a similar business. See, e.g., Roanoke Eng'g Sales Co. v. Rosenbaum, 290 S.E.2d 882, 885 (Va. 1982). As with other courts embracing the modern approach, Virginia court opinions tended to defer to the interests of employers and minimize the hardship on employees and the negative implications of such agreements on the public interest. See, e.g., Paramount Termite Control Co. v. Rector, 380 S.E.2d 922, 925 (Va. 1989).

However, the recent Virginia Supreme Court decisions depart from the modern approach by requiring a closer connection between the language of the noncompete agreement and the asserted interests of the employer. See Omniplex World Servs., Corp. v. U.S. Investigative Servs., Inc., 618 S.E.2d 340, 343 (Va. 2005); Modern Environments, Inc. v. Stinnett, 561 S.E.2d 694, 495-96 (Va. 2002); Simmons v. Miller, 544 S.E.2d 666, 678 (Va. 2001); Motion Control Sys., Inc. v. East, 546 S.E.2d 424, 426 (Va. 2001).

${ }^{163} 982$ P.2d 1277 (Ariz. 1999). 
practice, was unreasonably overbroad. ${ }^{164}$ Although prior to Valley Medical Specialists an Arizona appeals court had approved a similar restrictive covenant, ${ }^{165}$ in Valley Medical Specialists, the court adopted a more restrictive approach. The court also made several important pronouncements regarding the enforceability of employee noncompete agreements, both in general and specifically in the medical context.

Valley Medical Specialists (VMS), a professional corporation, hired Steven Farber, a pulmonologist, in 1985. He later became a shareholder, officer, and director of the firm. ${ }^{166}$ In 1991, Dr. Farber and the other VMS directors executed a stock and employment agreement that prohibited Dr. Farber from competing in the practice of medicine within five miles of any VMS office for three years. ${ }^{167}$ VMS sought to enforce the restrictive covenant when Dr. Farber left the firm and began practicing in violation of the agreement. ${ }^{168}$

Initially, the court had to resolve the threshold issue of the level of judicial scrutiny, which determined whether the agreement was subject to the more relaxed test applied in the sale-of-business context or to the demanding standard applied to employee noncompete agreements. ${ }^{169}$ The court determined that the shareholder agreement was more analogous to an employee noncompete agreement, in part because the primary concern of the law in protecting the goodwill purchased by a buyer of a business is not implicated when a professional partnership is split up. The court found strong public policy concerns in restricting a physician's practice, relying on the American Medical Association's policy of discouraging such agreements. ${ }^{170}$ It stopped short of declaring such noncompete agreements void per se, ${ }^{171}$ the position adopted by the trial

\footnotetext{
${ }^{164} I d$. at 1285 .

${ }^{165}$ Phoenix Orthopaedic Surgeons, Ltd. v. Peairs, 790 P.2d 752 (Ariz. Ct. App. 1989).

${ }^{166}$ Valley Medical Specialists, 982 P.2d at 1278-79.

${ }^{167} I d$. at 1279 .

${ }^{168}$ Id. at $1279-80$.

${ }^{169} I d$. at $1281-83$.

${ }^{170} I d$. at 1282 .

${ }^{171} I d$. at $1283 \mathrm{n} .1$. This is the position adopted by the recent Tennessee Supreme Court opinion in Murfreesboro Medical Clinic, P.A. v. Udom, 166 S.W.3d 674, 682 (Tenn. 2005).
} 
court ${ }^{172}$; however, it embraced a strict level of judicial scrutiny in light of the important public policy interests at stake. ${ }^{173}$

The court found that any goodwill interest of VMS in its patients was lessened because of the personal and professional nature of the physicianpatient relationship and the patient's strong interest in freedom of choice. ${ }^{174}$ Despite the lack of any strong goodwill interest in its patients, the court recognized VMS's interest in its referral services (protecting referrals from existing patients). But this referral service interest was obviously relatively weak in comparison to VMS's interest in its patients. ${ }^{175}$ This, in turn, limited the permissible scope of the noncompete agreement. ${ }^{176}$

In terms of the breadth of the noncompete agreement, the court found six months sufficient for VMS to find a replacement. ${ }^{177}$ The court also rejected the position of the court of appeals that public policy interests in preserving the physician-patient relationship were not adversely affected by the agreement: ${ }^{178}$ Finally, it rejected the approach of the appeals court, which had reformed the noncompete agreement. Although the Arizona courts follow the blue pencil doctrine, the lower court went too far by rewriting its terms. The court reiterated its adherence to the blue pencil doctrine. Nevertheless, it noted that even the blue pencil doctrine has potentially in terrorem effects on employees and, thus, it refused to allow broader reformation powers than under the common law approach. ${ }^{179}$

Valley Medical Specialists is significant in several respects. First, it applied principles of employee noncompete law in a new context: a restrictive covenant signed by an employee who also was an owner of the business. Arguments could be made that such an extension is un-

\footnotetext{
${ }^{172}$ Valley Medical Specialties, 982 P.2d at 1281-82.

${ }^{173} I d$. at 1283 .

${ }^{174} I d$.

${ }^{175} I d$. at 1284 .

${ }^{176} I d$. at $1284-85$.

${ }^{177} I d$.

${ }^{178} I d$. at 1285 ("Even if we assume other pulmonologists will be available to cover Dr. Farber's patients within the restricted area, we disagree with this view. It ignores the significant interests of individual patients within the restricted area.").

${ }^{179} I d$. at 1286.
} 
warranted and that the law's concerns with protecting employees from unreasonable noncompete agreements are not implicated in the partnership context, ${ }^{180}$ but the court rejected those arguments. ${ }^{181}$ Second, the court's approach to the scope of the agreement was quite restrictive. It accepted the rule that the permissible length of a noncompete is determined by the time necessary for a business to have a replacement employee. It found six months reasonable in a highly specialized field of medicine, ${ }^{182}$ which suggests that, in other less sophisticated fields, the time frame should be equally as limited. ${ }^{183}$ It also embraced the approach that a restrictive covenant is overly broad if it restricts an employee from engaging in activities unrelated to the prior employment. Finally, it limited the power of courts to reform an overbroad noncompete agreement under the blue pencil doctrine, preferring to continue with the more restrictive common law rule. ${ }^{184}$

In 2005, the Idaho Supreme Court rendered a significant opinion on the permissible scope of an employee noncompete agreement, in Freiburger v. J-U-B Engineers, Inc. ${ }^{185}$ Stephen Freiburger, an engineer and high-level manager with J-U-B Engineers, one of Idaho's largest engineering firms, signed a noncompete agreement at the time of his initial hire in 1991. Under it, Freiburger promised not to "take" any of J-U-B's past or present clients, projects, or pending clients or projects for a period of two years after termination. ${ }^{186}$ In 2001, he left J-U-B and went to work for another engineering firm, Riedesel Engineering. Then, in an action Freiburger

\footnotetext{
${ }^{180}$ For an excellent discussion of noncompete agreements in the professional context, see Serena L. Kafker, Golden Handcuffs: Enforceability of Non-Competition Clauses in Professional Partnership Agreements of Accountants, Physicians, and Attorneys, 31 Am. Bus. L.J. 31 (1993).

${ }^{181}$ Valley Medical Specialists, 982 P.2d at 1281.

${ }^{182} I d$. at $1284-85$.

${ }^{183}$ See, e.g., Bed Mart, Inc. v. Kelley, 45 P.3d 1219, 1223 (Ariz. Ct. App. 2002) (upholding a six-month noncompete period based on time to train new salesperson).

${ }^{184}$ See Varsity Gold v. Porzio, 45 P.3d 352, 358 (Ariz. Ct. App. 2002) (prohibiting reformation even if the resulting agreement is not "significantly different" from the original and even if there is a clause in the agreement allowing reformation).

${ }^{185} 111$ P.3d 100 (Idaho 2005).

${ }^{186} I d$. at 103.
} 
initiated to invalidate the noncompete agreement, the trial court found the agreement overbroad and unenforceable. ${ }^{187}$

The court found that J-U-B had a legitimate interest in the protection of its goodwill. ${ }^{188}$ However, in line with BDO Seidman, ${ }^{189}$ it defined this interest narrowly to apply to "customer relationships its former employee established and nurtured while employed by the employer." 190 Given this narrowly defined interest, the court found the noncompete agreement to be fatally overbroad. ${ }^{191} \mathrm{~J}-\mathrm{U}-\mathrm{B}$ had a huge client base, a product of its extensive engineering activities throughout the Northwest region for over thirty years. ${ }^{192}$ Because the noncompete covenant precluded Freiburger from doing work for any of these clients, it was not limited to those client relationships that Freiburger had either established or helped develop while at J-U-B. Moreover, the noncompete agreement prevented Freiburger from providing any services to J-U-B's past, current, or pending clients. ${ }^{193}$ This effectively prevented Freiburger from working in any capacity for one of J-U-B's clients.

$\mathrm{J}-\mathrm{U}-\mathrm{B}$ argued that, if the noncompete agreement was overbroad, then the court should modify its terms to render it reasonable under the approach adopted in Insurance Center Inc. v. Taylor. ${ }^{194}$ The Freiburger court declined to reform the covenant, however, because the agreement re-

\footnotetext{
${ }^{187} I d$. at 104 .

${ }^{188}$ As a preliminary matter, the Freiburger court addressed the standard of judicial scrutiny to be applied to the noncompete agreement. The covenant was in the nature of an antipiracy or nonsolicitation agreement, so the employer argued that the agreement should be subject to a less demanding standard of review. Id. at 104-05. Because antipiracy covenants are less onerous than general noncompete agreements, some courts have subjected them to a less stringent standard of reasonableness. Id . at 105 (citing Merrill Lynch, Pierce, Fenner \& Smith, Inc. v. Ran, 67 F. Supp. 2d 764 (E.D. Mich. 1999)). The Freiburger court rejected this approach, opting for the common law standard as to whether the covenant is "no more restrictive than necessary to protect the employer's legitimate business interests." Id. This standard, the court believed, could be readily applied to any noncompete agreement, regardless of its form. Id.

${ }^{189}$ See supra notes $152-61$ and accompanying text.

${ }^{190}$ Freiburger, 111 P.3d at 105 .

${ }^{191} I d$. at 106.

${ }^{192} I d$. at $106-07$.

${ }^{193} I d$. at 107 .

${ }^{194} 499$ P.2d 1252, 1256 (Idaho 1972) (adopting the reformation approach).
} 
quired substantial modifications to render it reasonable. ${ }^{195}$ The court concluded that the clause was fatally overbroad and unenforceable as a matter of law. ${ }^{196}$

Freiburger adopts an extremely restrictive approach to employee noncompete agreements, one that is similar to the Arizona Supreme Court's approach in Valley Medical Specialists. ${ }^{197}$ The permissible scope of an employee noncompete agreement designed to protect the goodwill of a business was limited in two respects. First, any noncompete agreement must be designed to prevent an employee from exploiting only those customer or client relationships that it helped create for the employer. Second, the type of competitive activities must be carefully defined to avoid overbreadth and indefiniteness. ${ }^{198}$ Just as important, the court's approach to reforming an overbroad noncompete agreement is quite restrictive. Substantial modifications of a noncompete agreement will not be permitted, only slight changes and the striking out of overbroad language. Although Insurance Center appeared to permit courts broader power to reform noncompete agreements, Freiburger prohibits courts from rewriting the terms of employee noncompete agreements. ${ }^{199}$

Consistent with Freiburger, the New Hampshire Supreme Court in 2005 adopted a restrictive approach to the protection of the goodwill interest. In Merrimack Valley Wood Products, Inc. v. Near, ${ }^{200}$ the court addressed the enforceability of a one-year noncompete agreement that prevented an outside sales representative (Near) from doing business with

\footnotetext{
${ }^{195}$ The court explained:

Here, it would be necessary not only to strike some of the words of the Covenant, but in addition, to add clauses relating to good will and relationships between Freiburger and the clients and defining the parameters of what services Freiburger would be prohibited from providing to J-U-B clients. This is far more than a 'blue pencil' approach to an unreasonable word or two and would have the district court or this Court re-writing the parties' contract.
}

111 P.3d at 108.

${ }^{196} I d$. at 106 .

${ }^{197}$ See supra notes $182-83$ and accompanying text.

${ }^{198}$ Freiburger, 111 P.3d at 106.

${ }^{199} I d$. at $107-08$.

${ }^{200} 876$ A.2d 757 (N.H. 2005). 
any customer of his former employers, Merrimack Valley Wood Products, Inc. and American Cabinet Corp. ${ }^{201}$

In analyzing the breadth of the noncompete covenant, the court reasoned that an employee's "special influence" over his employer's customers is a legitimate interest an employer may protect against competition. ${ }^{202}$ However, because Merrimack Valley Wood Products had 1,200 customers, only sixty of which Near regularly serviced, the former employee had no particular hold on those customers with whom he had no relationship. ${ }^{203}$ Because the noncompete agreement extended beyond Near's "sphere of customer goodwill," 204 it was broader than reasonably necessary to protect the former employer's legitimate interest. ${ }^{205}$

The Merrimack Valley court could have reformed the agreement and enforced it to the extent that it was reasonable. The court in Smith, Batchelder \& Rugg v. Foster ${ }^{206}$ had allowed reformation of a noncompete agreement as long as the employer acted in good faith. The trial court had found bad faith in that Near was not apprised of any noncompete obligation until he had worked for the companies for six months. The Merrimack Valley court reasoned that the lack of advance notice was not sufficient, standing alone, to constitute a lack of good faith. However, other facts supported the trial court's conclusion, including that the noncompete agreement was not discussed with Near during the oral negotiations and that the noncompete agreement was presented to Near on a "take it or leave it" basis at a time when he was in no position to negotiate, having already started work for the companies. ${ }^{207}$

Merrimack Valley requires an extremely close fit between the goodwill interest and the restriction on competition. The "sphere of customer influence" standard prevents a business from attempting to shield their entire customer base from competition from former employees. ${ }^{208}$

\footnotetext{
${ }^{201} I d$. at 762 .

${ }^{202} I d$. at $762-63$ (citations omitted).

${ }^{203} I d$. at $763-64$.

${ }^{204} I d$. at 764 .

${ }^{205} I d$. at $763-64$.

${ }^{206} 406$ A.2d 1310 (N.H. 1979).

${ }^{207}$ Merrimack Valley, 876 A.2d at 765.

${ }^{208} I d$. at 763 .
} 
Merrimack Valley is also significant because it is part of an emerging trend limiting the power of courts to reform overbroad noncompete agreements. Merrimack Valley provides some process-based standards to judge whether an employer has truly acted in good faith. Like Freiburger's substantive approach to the good faith requirement, ${ }^{209}$ the opinion suggests that, if an employer overreaches in the drafting or negotiating of a noncompete covenant, it may be invalidated in its entirety.

\section{Tightened Statutory Restrictions on Employee Noncompete Agreements}

Recent statutory developments parallel the heightened judicial scrutiny of employee noncompete agreements under the common law reasonableness standard. Opinions narrowly interpreting employee noncompete statutes, and the adoption of a new restrictive statute in Oklahoma, demonstrate another emerging trend: the tightening of statutory restrictions on employee covenants not to compete.

In 2001 Oklahoma adopted an extremely restrictive employee noncompete statute. ${ }^{210}$ The new law, Section $219 \mathrm{~A}$, allows only one type of noncompete agreement, a nonsolicitation agreement preventing an employee from directly soliciting the established customers of the former employer's business. ${ }^{211}$ The history of the Oklahoma statute is instructive. Prior to the passage of Section 219A, the Oklahoma courts had interpreted the state's restraint of trade statute in a permissive fashion, applying a reasonableness analysis to employee noncompete agreements. ${ }^{212}$ But in Loewen Group Acquisition Corporation v. Matthews, ${ }^{213}$ the Oklahoma Court of Civil Appeals invalidated a noncompete agreement in an opinion that set the stage for the new statute. In that case, the manager of a funeral home business, Matthews, was required to sign a noncompete agreement when the business was acquired by the Loewen Group. ${ }^{214}$ The covenant

\footnotetext{
${ }^{209}$ See Freiburger, 111 P.3d at 107-08. See also supra notes 185-96 and accompanying text.

${ }^{210}$ Oкц. Stat. Ann. tit. 15, § 219A (Supp. 2007).

${ }^{211} I d$. Other forms of employee restrictive covenants are prohibited under Oklahoma's general restraint of trade statute. Окца. Sтат. Ann. tit. 15, § 217 (Supp. 2007).

${ }^{212}$ See, e.g., Bayly, Martin \& Fay, Inc. v. Pickard, 780 P.2d 1168, 1170-71 (Okla. 1989). See also supra notes 127-29 and accompanying text.

${ }^{213} 12$ P.3d 977 (Okla. Civ. App. 2000).

${ }^{214} I d$. at 978 .
} 
prohibited Matthews from engaging in any competing funeral home business within fifteen miles of a Loewen Group business for a period of three years after termination of his employment with Loewen Group. ${ }^{215}$ Matthews had extensive experience and contacts in the community, most of which had been acquired before the takeover of the funeral homes by the Loewen Group. ${ }^{216}$ The Court of Civil Appeals found that the agreement was inherently unreasonable because Matthews was not using some competitive advantage or opportunity from his employment to compete with the Loewen Group. ${ }^{217}$

Section 219A essentially codifies the holding in Loewen. The statute is quite restrictive. Only agreements restricting an employee from "directly solicit[ing]" the "established customers of the former employer" are permitted under the statute. ${ }^{218}$ It would appear, therefore, that not only general noncompete agreements are unenforceable, but also agreements that would prohibit a former employee from servicing or doing work for established customers who contact or initiate the contract with the former employee. The "directly solicit" language would appear to be limited to active steps (for example, phone calls, direct marketing) on the part of a former employee to get business from established customers of the former employer. $^{219}$

Similar in effect to the enactment of the Oklahoma statute, the North Dakota and Louisiana Supreme Courts have issued opinions narrowly interpreting their noncompete statutes, ${ }^{220}$ and the California Court of

\footnotetext{
${ }^{215} I d$. at $978-79$.

${ }^{216} I d$. at $980-81$.

${ }^{217} I d$. at 982 .

${ }^{218}$ OкLa. Stat. Ann. tit. 15, § 219A(a) (Supp. 2007).

${ }^{219}$ See Michael E. Chionopoulos, Covenants Not to Compete Could Create Competition in the Courtroom, 73 Окца. В.J. (2002), available at http://www.okbar.org/obj/articles_02/ sa040602.htm.
}

${ }^{220}$ SWAT 24 Shreveport Bossier, Inc. v. Bond, 808 So. 2d 294, 296 (La. 2001) (“[W]e interpret the limited exception found in [the Louisiana non-compete statute] to the general nullity of such agreements to apply only to those agreements in which the employee agrees to refrain from carrying on or engaging in his own business similar to that of the employer."); Warner \& Co. v. Solberg, 634 N.W.2d 65, 71 (N.D. 2001) (refusing to create judicial exceptions to the statute in the face of the statute's plain language).

In SWAT 24, the court interpreted the statute to allow only employee noncompete agreements where the employee carries on his own competing business, thereby refusing to 
Appeals has recently rejected a "narrow restraint" exception to Section 16600. ${ }^{221}$ In Warner and Company v. Solberg, ${ }^{222}$ the North Dakota Supreme Court was urged to create a trade secret exception to the restraint of trade statute, which would permit nonsolicitation agreements designed to protect confidential customer lists. ${ }^{223}$ The argument for such an exception was supported by case law from California that had recognized a trade secret exception to Section $16600,{ }^{224}$ and the Eighth Circuit's decision in Kovarik v. American Family Insurance, ${ }^{225}$ which upheld a one-year nonsolicitation agreement under North Dakota law. ${ }^{226}$

Despite the persuasive authority in favor of a limited customer-list exception, the North Dakota court declined to create one. The court placed reliance on the clear language of the statute, the history of noncompete law in North Dakota, and the adoption of the Uniform Trade Secrets Act (UTSA) ${ }^{227}$ in the state. First, the court considered the plain meaning of the statute an unambiguous declaration of legislative intent that any restraint on a person's right to engage in a profession or business is unlawful as a matter of public policy. ${ }^{228}$ Second, the court noted that

enforce a noncompete agreement that prevented the employee from going to work for a competing business. 808 So. $2 \mathrm{~d}$ at 307,310 . The Louisiana legislature modified the language of the relevant statute to overrule SWAT 24. See La. Rev. Stat. Ann. § 23:921D (Supp. 2007).

${ }^{221}$ The California Court of Appeals, in Edwards v. Arthur Andersen, LLP, 47 Cal. Rptr. 3d 788 (Cal. Ct. App.), rev. granted, 147 P.3d 1013 (Cal. 2006), refused to follow the Ninth Circuit's exception that allows noncompete agreements to restrict employees from a "small" segment of a particular business or trade, concluding that the exception is inconsistent with the language and history of Section 16600, with case law interpreting the statute, and contrary to the public policies underlying the law. Id. at 800-03. The California Supreme Court has granted review in the case, 147 P.3d at 1013.

${ }^{222} 634$ N.W.2d 65 (N.D. 2001).

${ }^{223} I d$. at $69-70$.

${ }^{224}$ See supra notes 63-64 and accompanying text. Because the North Dakota statute (Section 908-06) is derived from the same Field Code provision as the California noncompete law, the North Dakota courts have given weight to California opinions interpreting the restraint of trade statute. Solberg, 634 N.W.2d at 70.

${ }^{225} 108$ F.3d 962 (8th Cir. 1997).

${ }^{226} I d$. at 967 .

${ }^{227}$ Unif. Trade Secrets Act $\S \S 1-11$ (amended 1985), 14 U.L.A. 434 (1990). See infra note 256 for a list of other states that have adopted the UTSA.

${ }^{228}$ Solberg, 634 N.W.2d at 71-72. 
attempts to amend the statute in the legislature to allow nonsolicitation agreements had failed. ${ }^{229}$ Finally, the court reasoned that the California decisions preceded the adoption of the UTSA in California. ${ }^{230}$ In light of North Dakota's adoption of the UTSA, the court questioned the need to create a judicial exception for the protection of trade secrets. ${ }^{231}$ Thus, the court took a restrictive view of the noncompete law despite substantial authority for the creation of a limited judicial exception.

\section{Summary}

The emerging law of employee noncompete agreements significantly restricts the power of employers to impose postemployment restrictions on competition. What the trend of recent case law suggests is that the courts are returning to the restrictive traditional approach to employee noncompete agreements and moving away from the more permissive modern standards. These opinions have made it more difficult for employers to draft and to enforce covenants not to compete in the employment setting. Employers attempting to restrict former employees from engaging in competitive activities under the inevitable disclosure doctrine have faced a similar hostile legal environment. As we discuss in the next section, many courts have limited the reach of the inevitable disclosure doctrine in the interests of employee mobility and open competition.

\section{THE EMERGING LAW: LIMITING THE IMPOSITION OF DE FACTO NONCOMPETE AGREEMENTS UndeR THE Inevitable Disclosure Doctrine}

The 1995 opinion of the Seventh Circuit Court of Appeals in PepsiCo v. Redmond ${ }^{232}$ created renewed interest in the inevitable disclosure doctrine

\footnotetext{
${ }^{229} I d$. at 71 .

${ }^{230} I d$. at 72 .

${ }^{231} I d$.

${ }^{232} 54$ F.3d 1262 (7th Cir. 1995). For recent commentary on the doctrine, see generally Renee Cavalovitch, The Inevitable Demise of "Inevitable Disclosure" in California: Appellate Court Rejects the Doctrine in Schlage Lock Co. v. Whyte, 22 J.L. \& Com. 37 (2002); Adam Gill, The Inevitable Disclosure Doctrine: Inequitable Results are Threatened but not Inevitable, 24 Hastings Comm. \& ENT.
} 
under which a court can enjoin a former employee from working for a competitor of the employer to prevent an imminent threat of a trade secret misappropriation. ${ }^{233}$ Under the doctrine, an injunction preventing employment can issue even if the employee is not bound by a noncompete agreement and without any showing of an actual misappropriation of trade secrets. ${ }^{234}$ Traditionally, the courts invoked inevitable disclosure to prevent a competitor from unlawfully securing protected technology by hiring away an employee with knowledge of specialized and highly valuable trade secrets. ${ }^{235}$ But in PepsiCo, the Seventh Circuit developed a new formulation for the inevitable disclosure doctrine under the UTSA, ${ }^{236}$ one that is not as restrictive as the traditional common law approach.

\section{A. The Development of the Common Law Doctrine of Inevitable Disclosure}

The inevitable disclosure doctrine preceded the widespread adoption of the UTSA and the PepsiCo decision. ${ }^{237}$ As a matter of common law, the doctrine developed in a series of cases involving the threatened misuse of valuable, technical trade secrets by former employees hired away by competitors seeking to gain entry into highly competitive markets. Thus, the doctrine in its infancy was designed to prevent an imminent threat of a trade secret disclosure by a former employee, a particularly damaging form of unfair competition. The leading case is E.I. duPont de Nemours E

L.J. 403 (2002); Eleanore R. Godfrey, Inevitable Disclosure of Trade Secrets: Employee Mobility v. Employer's Rights, 3 J. High Tech. L. 161 (2004); Joseph F. Phillips, Inevitable Disclosure Through an Internet Lens: Is the Doctrine's Demise Truly Inevitable?, 45 WM. \& MARY L. REv. 395 (2003); Elizabeth A. Rowe, When Trade Secrets Become Shackles: Fairness and the Inevitable Disclosure Doctrine, 7 Tul. J. Tech. \& Intell. Prop. 167 (2005); Brandy L. Treadway, An Overview of Individual States' Application of Inevitable Disclosure: Concrete Doctrine or Equitable Tool?, 55 SMU L. Rev. 621 (2002).

${ }^{233}$ The inevitable disclosure doctrine is the "legal theory that a key employee, once hired by a competitor, cannot avoid misappropriating the former employer's trade secrets." BLACK's LAW Dictionary (8th ed. 2004).

${ }^{234}$ PepsiCo, 54 F.3d at 1270-71.

${ }^{235}$ See infra Part VI.A, discussing DuPont and Allis-Chalmers cases.

${ }^{236}$ Unif. Trade Secrets Act $\S \S 1-11$ (amended 1985), 14 U.L.A. 434 (1990).

${ }^{237}$ For an insightful discussion of the common law inevitable disclosure doctrine, see generally Lawrence I. Weinstein, Revisiting the Inevitability Doctrine: When can a Former Employee who never Signed a Non-Compete Agreement nor Threatened to Use or Disclose Trade Secrets be Prohibited from Working for a Competitor, 21 Am. J. Trial Advoc. 211 (1997). 
Co. [DuPont] v. American Potash \& Chemical Corp., ${ }^{238}$ in which the Delaware Chancery Court granted an injunction in favor of DuPont against a former employee who had access to a valuable trade secret process. Donald Hirsch, a chemical engineer with a doctorate degree, had been involved in the long and expensive effort to develop DuPont's chloride process for manufacturing certain pigments. ${ }^{239}$ After American Potash was unsuccessful in securing a license from DuPont for that process, it decided to develop its own chloride process. As part of that initiative, it hired Hirsch as a technical manager for a new pigment manufacturing plant. ${ }^{240}$ DuPont brought suit to enforce its confidentiality agreement, and it secured a preliminary injunction stopping Hirsch from working for American Potash in the field of chloride process development. ${ }^{241}$

In rejecting a summary judgment motion made by the defendants, the court relied on the inevitability of the disclosure of the trade secrets by Hirsch in finding a sufficient threat of improper disclosure. The court viewed inevitability as a factor that it was justified in considering in weighing the probabilities of a trade secret disclosure. ${ }^{242}$ The court reasoned that the protection of trade secrets is important to society because it encourages investment in $\mathrm{R} \& \mathrm{D}$, although there is also a strong countervailing interest in protecting the employee's right to use knowledge and skills that may be "inextricably interwoven with his knowledge of the trade secrets." ${ }^{243}$ Given other facts pointing to the probability of an unlawful disclosure, including a statement by Hirsch conceding the potential for a conflict of interest occurring in his employment with American Potash, ${ }^{244}$ the court left the ultimate resolution for trial, with the preliminary injunction in place to preserve the status quo. ${ }^{245}$

The DuPont opinion was followed by the federal district court opinion in Allis-Chalmers Manufacturing Company v. Continental Aviation and Engineer-

\footnotetext{
${ }^{238} 200$ A.2d 428 (Del. Ch. 1964).

${ }^{239} I d$. at $429-30$.

${ }^{240} I d$. at 431.

${ }^{241} I d$. at $429-30$.

${ }^{242} I d$. at 436 .

${ }^{243} I d$. at 437 .

${ }^{244} I d$. at 435 .

${ }^{245} I d$. at 437 .
} 
ing Corporation, ${ }^{246}$ a case that bore a striking factual similarity to DuPont. Allis-Chalmers marketed a specialized type of fuel injector pump. At that time, only three companies marketed this type of pump, and at least eight American and foreign companies had attempted but failed to develop comparable equipment. ${ }^{247}$ Allis-Chalmers negotiated with Continental Aviation regarding the sale of its distributor pumps, but Continental rejected a licensing agreement that would have granted Continental the right to use Allis-Chalmers' patent and trade secret rights in the manufacture of pumps for the military. ${ }^{248}$ The negotiations having failed, Continental hired George Wolff, an engineer who was instrumental in the development of Allis-Chalmers' distributor pump, to work on the design and development of Continental's fuel injection systems and pumps. $^{249}$

In granting a preliminary injunction, which prevented Wolff from doing certain work for Continental, the court found an "inevitable and imminent" risk of trade secret misappropriation. ${ }^{250}$ This was based on the "negotiations, relating to distributor type fuel injection pumps ... the nature of the research and development work done by Mr. Wolff ... at Allis-Chalmers, [and] the nature of the type of work Mr. Wolff is to perform at Continental."251 Given these facts, the court noted the "virtual impossibility of Mr. Wolff performing all of his prospective duties for Continental to the best of his ability, without in effect giving it the benefit of AllisChalmers' confidential information.",252

The court granted an injunction that prevented Wolff from working in the design of distributor-type pumps, but that allowed him to work for Continental on other projects, including other pumps and fuel injection systems. ${ }^{253}$ As in DuPont, the court was mindful of the competing legal principles at play and the need to protect the rights of employees to market

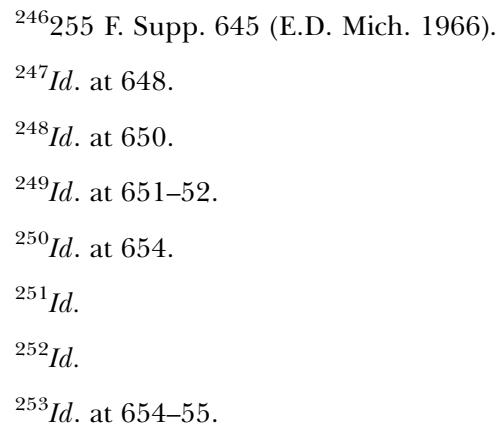


their general knowledge and skills while at the same time protecting the intellectual property of employers. ${ }^{254}$ It therefore provided a limited preliminary injunction, one that was narrowly tailored to protect the threatened trade secrets. ${ }^{255}$

Allis-Chalmers and DuPont represent the prevailing approach to the inevitable disclosure doctrine prior to PepsiCo. Both cases involved highly specialized and technical trade secrets that gave the businesses a substantial advantage in the market. Both also involved competitors that were apparently attempting to acquire the protected technology by hiring away high-level scientific personnel. Finally, the former employees would not have been able to perform their new responsibilities without using or disclosing their former employer's trade secrets. Because there was an imminent threat of misappropriation, and an injunction against disclosure would not have been an adequate remedy, the courts granted narrow injunctions preventing employment of the former employees in positions where trade secrets were at risk.

\section{B. The PepsiCo Formulation of Inevitable Disclosure}

PepsiCo may not have been the first decision on inevitable disclosure, but it was the first major case of inevitable disclosure decided under the UTSA standards relating to a "threatened" misappropriation of a trade secret. ${ }^{256}$ Thus, PepsiCo has become the leading case on the doctrine, with courts fashioning rules of inevitable disclosure based in large measure on the PepsiCo facts and the Seventh Circuit's legal reasoning. ${ }^{257}$ It is imperative,

\footnotetext{
${ }^{254} I d$. at 654 .

${ }^{255} I d$. at $654-55$.

${ }^{256}$ The UTSA has been adopted in forty-four states and the District of Columbia. See Uniform Law Commissioners, A Few Facts About the Uniform Trade Secrets Act, http://www.nccusl.org/ Update/uniformact_factsheets/uniformacts-fs-utsa.asp (last visited Sept. 26, 2007). The following seven states adopted the original 1979 version of the UTSA: Arkansas, California, Connecticut, Indiana, Louisiana, Rhode Island, and Washington. Id. The District of Columbia and the following thirty-seven states adopted the UTSA as amended in 1985: Alabama, Alaska, Arizona, Colorado, Delaware, Florida, Georgia, Hawaii, Idaho, Illinois, Iowa, Kansas, Kentucky, Maine, Maryland, Michigan, Minnesota, Mississippi, Missouri, Montana, Nebraska, Nevada, New Hampshire, New Mexico, North Dakota, Ohio, Oklahoma, Oregon, Pennsylvania, South Carolina, South Dakota, Tennessee, Utah, Vermont, Virginia, West Virginia, and Wisconsin. Id.
}

${ }^{257}$ See infra note 279 . 
therefore, to understand the court's rationale in PepsiCo to fully appreciate the modern inevitable disclosure doctrine, its limitations and qualifications, and its implications for employee mobility.

The dispute in PepsiCo arose out of the soda wars of the 1990s. Quaker Oats held the dominant position in the sports-drink segment of the market with its popular Gatorade brand. PepsiCo had entered the market with the All Sport brand in $1994 .{ }^{258}$ In addition, the companies were rivals in the new-age-drink segment of the market, with Quaker Oats having a similar advantage because of its Snapple fruit drinks. ${ }^{259}$ PepsiCo intended to increase its share of this segment in 1995 by capitalizing on joint ventures with Ocean Spray Cranberries and Thomas J. Lipton Company. William Redmond, a high-level executive with PepsiCo, took a similar position with Quaker Oats in November $1994 .{ }^{260}$ Redmond had participated in the development of PepsiCo's marketing plans and strategies for 1995, including sensitive information about "pricing architecture" and "attack plans" for specific markets. ${ }^{261}$ When Redmond went to work for Quaker Oats, PepsiCo brought suit against Redmond and Quaker Oats claiming an imminent threat of trade secret misappropriation. The district court issued an injunction preventing Redmond from assuming his position with Quaker Oats for a period of six months, a noncompete period necessary to protect the heart of PepsiCo's trade secrets, its strategic plans for $1995 .^{262}$

After reviewing case law and the Illinois Trade Secret Act, ${ }^{263}$ the PepsiCo court concluded that "a plaintiff may prove a claim of trade secret misappropriation by demonstrating that defendant's new employment will inevitably lead him to rely on the plaintiff's trade secrets." ${ }^{264}$ In finding that PepsiCo demonstrated a likelihood of success on its misappropriation claim, the court relied on three circumstances. First, Redmond had "extensive and intimate knowledge" of PepsiCo's strategies for

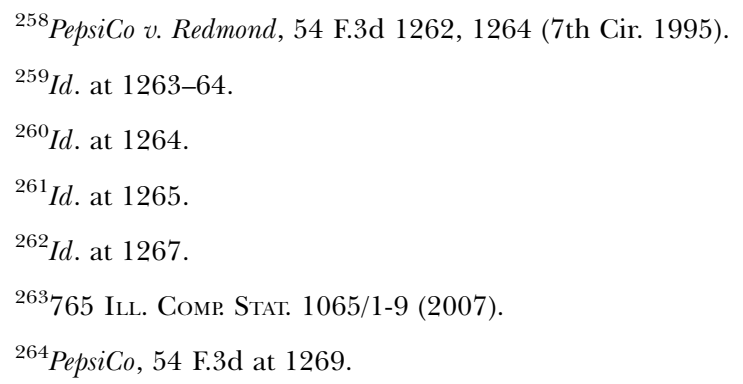


1995. ${ }^{265}$ Armed with that knowledge, Quaker Oats could achieve a "substantial advantage" by making decisions for Quaker Oats that would effectively respond to PepsiCo's marketing plans and actions. ${ }^{266}$ Second, given the nature of Redmond's position with Quaker Oats, it was impossible for him not to use his knowledge of PepsiCo's strategies because he would be making decisions with that information in mind. ${ }^{267}$ Unless he had an "uncanny ability to compartmentalize information," he would undoubtedly use his knowledge of PepsiCo's plans and strategies in his position at Quaker Oats. ${ }^{268}$ Finally, the circuit court cited Redmond's apparent lack of candor, as determined by the district court, ${ }^{269}$ to support its conclusion that misappropriation was inevitable, even as it conceded that his conduct may have been innocent. ${ }^{270}$

Despite the court's seemingly reasonable interpretation of the facts, the case for inevitable disclosure in PepsiCo was not as strong as in DuPont. First, PepsiCo did not involve the type of technical, resource-intensive, and highly valuable trade secrets at risk in DuPont. Although the marketing information in PepsiCo was properly considered a trade secret ${ }^{271}$ the value of this type of soft managerial information to a competitor is not as apparent as the type of hard technical information in DuPont. Second, the intent to secure protected technology by hiring away a knowledgeable employee is not clear from the circumstances in PepsiCo. Redmond was hired by the dominant player in the market, ${ }^{272}$ not a competitor attempting to develop unlawfully technology that it was unable to develop lawfully. Therefore, the argument for the inevitability of a trade secret disclosure is not as strong as it was in DuPont. Finally, the evidence that Redmond would use this marketing information, or that it would be impossible for him not to use it, is not as compelling as in DuPont. The distribution channels employed by PepsiCo and Quaker Oats were

\footnotetext{
${ }^{265} I d$.

${ }^{266} I d$. at 1270 .

${ }^{267} I d$. at 1269 .

${ }^{268} I d$.

${ }^{269} I d$. at 1270 .

${ }^{270} I d$. at 1271 .

${ }^{271} I d$. at 1268 .

${ }^{272} I d$. at $1264,1265$.
} 
different ${ }^{273}$ and Redmond ostensibly was hired to integrate the distribution of the Gatorade and Snapple lines under a preexisting company plan. ${ }^{274}$ Although knowledge of PepsiCo's strategies might be useful to Quaker Oats, it would appear to have limited value to Redmond in his new position.

PepsiCo is a significant expansion of the common law inevitable disclosure doctrine. The court's approach changes both the focus and critical elements of an inevitable disclosure case. Under DuPont, the focus was on preventing a form of competition by former employees that involves a high probability of a trade secret misappropriation. ${ }^{275}$ Under the common law approach, the determinative factors are (1) the existence of valuable, technical, and specialized trade secrets giving the former employer a strong position in the market; (2) the hiring away of employees with knowledge of those trade secrets in an attempt by a competitor to improperly secure that technology; and (3) employment of the former employee in a position where it would be impossible for the employee to perform without using the trade secret information. ${ }^{276}$ If such elements are present, a limited noncompete injunction is necessary to prevent an imminent threat of a trade secret misappropriation.

PepsiCo focuses on the need to protect businesses from all forms of competition by former employees who are hired by direct competitors in situations where the potential exists for the former employees to exploit knowledge acquired in their prior employment. The key PepsiCo factors are (1) the degree of competition between the new and former employers, (2) the closeness between the employee's old and new positions, and (3) the extensiveness of the former employee's knowledge of technical or managerial trade secrets. ${ }^{277}$ Evidence of bad faith on the part of the employee provides support for but is not essential to a finding of

\footnotetext{
${ }^{273} I d$. at 1264 .

${ }^{274} I d$. at 1265 .

${ }^{275}$ See supra notes $238-45$ and accompanying text.

${ }^{276}$ See Jonathan O. Harris, Note, The Doctrine of Inevitable Disclosure: A Proposal to Balance Employer and Employee Interests, 78 WASH. U. L.Q. 325, 328 (2000).
}

${ }^{277}$ See Proctor \& Gamble v. Stoneham, 747 N.E.2d 268, 279 (Ohio Ct. App. 2000) (“According to the inevitable-disclosure rule, a threat of harm warranting injunctive relief can be shown by facts establishing that an employee with detailed and comprehensive knowledge of an employer's trade secrets and confidential information has begun employment with a competitor of the former employer in a position that is substantially similar to the position held during the former employment."). 
inevitable disclosure under PepsiCo. ${ }^{278}$ Because wrongful intent is not an essential element under the PepsiCo formulation, the burden on the former employer to prove inevitability is not as demanding as under the common law standard. Essentially, the PepsiCo court developed a new model of the typical inevitable disclosure case. Thus, PepsiCo represents a fundamental legal paradigm shift.

PepsiCo has had a significant impact on the inevitable disclosure doctrine. Subsequent to the Seventh Circuit's opinion, many state and federal courts adopted the inevitable disclosure doctrine ${ }^{279}$ or considered it in trade secret litigation without expressly adopting it. ${ }^{280}$ Most have also followed the PepsiCo court's logic and its formulation of the doctrine, employing the factors identified in the opinion on the inevitability question. ${ }^{281}$ Although the courts that have embraced inevitable disclosure have not done so in an entirely consistent fashion, ${ }^{282}$ the doctrine is now considered the majority rule. ${ }^{283}$

\footnotetext{
${ }^{278}$ PepsiCo, 54 F.3d at 1262.

${ }^{279}$ E.g., RKI, Inc. v. Grimes, 177 F. Supp. 2d 859, 875-77 (N.D. Ill. 2001); Lexis-Nexis v. Beer, 41 F. Supp. 2d 950, 959 (D. Minn. 1999); Strata Mktg., Inc. v. Murphy, 740 N.E.2d 1166, 1178 (Ill. App. Ct. 2000); Sw. Energy Co. v. Eickenhorst, 955 F. Supp. 1078, 1085 (W.D. Ark. 1997), aff'd, 175 F.3d 1025 (8th Cir. 1999). Though influential, PepsiCo obviously was not the origin of the inevitable disclosure doctrine. See, e.g., Nat'l Starch \& Chem. Corp. v. Parker Chem. Corp., 530 A.2d 31, 33 (N.J. Sup. Ct. App. Div. 1987) (adopting the inevitable disclosure doctrine prior to the decision in PepsiCo). See also Merck \& Co. v. Lyon, 941 F. Supp. 1443, 1460 (M.D.N.C. 1996) (finding that the PepsiCo factors which consider "the degree of competition between the former and new employer, and the new employer's efforts to safeguard the former employer's trade secrets, and the former employee's 'lack of forthrightness'... and ... . the degree of similarity between the former employee's former and current position," were consistent with previous North Carolina decisions).
}

${ }^{280}$ E.g., Bridgestone/Firestone, Inc. v. Lockhart, 5 F. Supp. 2d 667, 681-82 (S.D. Ind. 1998) (discussing the doctrine and PepsiCo but concluding that the record would not support a finding of inevitable disclosure).

${ }^{281}$ See, e.g., Lexis-Nexis, 41 F. Supp. 2d at 959; Eickenhorst, 955 F. Supp. at 1085; Uncle B's Bakery, Inc. v. O’Rourke, 920 F. Supp. 1405, 1435-36 (N.D. Iowa 1996); La Calhene v. Spolyar, 938 F. Supp. 523, 531 (W.D. Wis. 1996); Stoneham, 747 N.E.2d at 278-80.

${ }^{282}$ Treadway, supra note 232, at 623 ("In drawing a comparison between the states, it becomes apparent that no two enforce the same version of inevitable disclosure.").

${ }^{283}$ Whyte v. Schlage Lock Co., 125 Cal. Rptr. 2d 277, 291 (Cal. Ct. App. 2002). (“Our survey confirms the majority of jurisdictions addressing the issue have adopted some form of the inevitable disclosure doctrine."). 


\section{The Judicial Assault on the Inevitable Disclosure Doctrine}

The PepsiCo opinion triggered a significant amount of scholarly criticism, most of it directed at the doctrine's negative effects on employees. ${ }^{284}$ Critics argue that the adoption of the PepsiCo formulation has the potential to allow employers to circumvent employee noncompete law and thereby upset the delicate policy balance between an employee's interest in mobility and an employer's interest in protecting its proprietary information. ${ }^{285}$ In apparent response to the policy implications of the inevitable disclosure doctrine, many courts have retreated from the broadest reading of PepsiCo or have rejected the doctrine outright. This subsection addresses the various avenues of retreat that such courts have followed.

Some jurisdictions applying the inevitable disclosure doctrine have given it a limited or narrow reach by requiring more than the "inevitability" evidence of PepsiCo. ${ }^{286} H \& R$ Block Eastern Tax Services, Inc. $v$. Enchura $^{287}$ is illustrative. In Enchura, the employees (Enchura and Fortner) were both regional directors for $\mathrm{H} \& \mathrm{R}$ Block who were hired away by major competitors of the tax return preparation firm. ${ }^{288}$ Although their primary responsibility as regional directors was the management of the company-owned offices, both employees were privy to trade secret information, including information from a Tax Operations National Meeting in September that they both attended before they quit. ${ }^{289}$

The Enchura court found that "demonstrated inevitability alone is insufficient to justify injunctive relief; rather, demonstrated inevitability in

\footnotetext{
${ }^{284}$ E.g., John H. Matheson, Employee Beware: The Irreparable Damage of the Inevitable Disclosure Doctrine, 10 Loy. Consumer L. Rev. 145 (1998); Susan Street Whaley, The Inevitable Disaster of Inevitable Disclosure, 67 U. CIN. L. Rev. 809 (1999); Rebecca J. Berkun, Comment, The Dangers of the Doctrine of Inevitable Disclosure in Pennsylvania, 6 U. PA. J. LAB. \& EMP. L. 157 (2003); Johanna L. Edelstein, Note, Intellectual Slavery?: The Doctrine of Inevitable Disclosure of Trade Secrets, 26 Golden Gate U. L. Rev. 717 (1996).

${ }^{285}$ See, e.g., Matheson, supra note 284, at 160 ; Whaley, supra note 284 , at 836 ; Berkun, supra note 284 , at $173-75$.

${ }^{286}$ E.g., IBM v. Seagate Tech., 941 F. Supp. 98, 101 (D. Minn. 1992) (requiring a high probability of inevitable disclosure, noting that mere possession of trade secrets and the former employee holding similar position with a competitor are insufficient to sustain that burden).

${ }^{287} 122$ F. Supp. 2d 1067 (W.D. Mo. 2000).

${ }^{288} I d$. at $1070,1072$.

${ }^{289} I d$. at $1070-71$.
} 
combination with a finding that there is an unwillingness to preserve confidentiality is required." 290 "To prevail under this theory, employers must demonstrate inevitability exists with facts indicating that the nature of the secrets at issue and the nature of the employee's past and future work justify an inference that the employee cannot help but consider secret information." 291 Applying these restrictive standards, the court concluded that there was insufficient evidence to support a claim of inevitability and no showing of unwillingness on the part of Enchura and Fortner to respect the confidentiality of H \& R Block's trade secrets. ${ }^{292}$ The former employees would not be making decisions in the same areas covered by the trade secrets. Thus, there was minimal risk that they could exploit the information. ${ }^{293}$ Also, unlike in PepsiCo, they had not participated in the development of the marketing plans. ${ }^{294}$ Nor could they have easily memorized the voluminous information presented at the September meeting. ${ }^{295}$ Thus, a finding of inevitable disclosure was not justified by the facts.

Cases like Enchura ${ }^{296}$ represent a retreat from the more expansive view of PepsiCo adopted by some courts. ${ }^{297}$ Enchura's requirement of inevitability plus ${ }^{298}$ imposes a heavy burden on former employers to demonstrate a real threat of a trade secret misappropriation. Enchura and other court opinions requiring inevitability plus may reflect dissatisfaction with the utility of the PepsiCo formulation. Because the PepsiCo factors will often exist in any case where a high-level employee takes a

\footnotetext{
${ }^{290} I d$. at 1075 (emphasis in original).

${ }^{291} I d$. at 1076 .

${ }^{292} I d$. at $1075-76$.

${ }^{293} I d$. at 1075 .

${ }^{294} I d$. at 1072,1075 .

${ }^{295} I d$. at 1071 .

${ }^{296}$ See, e.g., Uncle B's Bakery v. O'Rourke, 920 F. Supp. 1405 (N.D. Iowa 1996); Novell, Inc. v. Timpanogos Research Group, Inc., 46 U.S.P.Q.2d (BNA) 1197 (Utah D. Ct. 1998).

${ }^{297}$ See, e.g., Procter \& Gamble Co. v. Stoneham, 747 N.E.2d 268 (Ohio 2000).

${ }^{298}$ This phrase was coined by the court in Del Monte Fresh Produce Co. v. Dole Food Co., Inc., 148 F. Supp. 2d 1326 (S.D. Fla. 2001), in which the court rejected the PepsiCo doctrine of inevitable disclosure. Id. at 1336-37. Citing to Enchura, the court reasoned that mere possession of trade secrets is insufficient to prove a threatened misappropriation. To demonstrate a substantial threat, inevitability and an unwillingness to preserve confidentiality is necessary, the "inevitability-plus requirement." Id. at 1338.
} 
position with a competitor, the courts need other factors to differentiate between a potential misuse of trade secrets by a former employee and an inevitable one.

Most recently, several jurisdictions have either rejected the inevitable disclosure doctrine outright or have seriously questioned its legitimacy from a public policy standpoint. Concern has focused primarily on the negative effects the doctrine has on the rights of employees. In particular, courts note that imposing a de facto noncompete agreement without the employee's consent is unfair. ${ }^{299}$ In addition, courts are concerned about broadening postemployment restrictions on employees under the guise of trade secret protection. ${ }^{300}$

Whether California would follow the PepsiCo lead in light of its restrictive employee noncompete statute was unclear for some time. ${ }^{301}$ The issue was definitively resolved in 2002 with the California appeals court opinion in Whyte v. Schlage Lock Co., ${ }^{302}$ a case that bore a striking resemblance to PepsiCo. The litigation involved two competitors in the manufacture and sale of locks and related products, Schlage Lock Co. and Kwikset. ${ }^{303}$ As the vice president of sales for Schlage, Whyte was responsible for sales to "big box" retailers, including Home Depot. He had successfully negotiated a "line review" agreement with Home Depot that expanded Schlage's presence on the retailer's shelves and removed Kwikset's Titan brand. ${ }^{304}$ Impressed with Whyte's skills, Kwikset's president hired him away from Schlage. Whyte accepted the position on June 3, 2000, but did not formally resign until after a confidential meeting

\footnotetext{
${ }^{299}$ See infra notes 309-10 \& 334-35 and accompanying text.

${ }^{300}$ See infra notes 315-19 and accompanying text.

${ }^{301}$ In Electro Optical Industries, Inc. v. White, 90 Cal. Rptr. 2d 680 (Cal. Ct. App. 1999), a California appeals court expressly adopted the doctrine. Id. at 684. This opinion was later ordered to be unpublished by the California Supreme Court. Electro Optical Indus., Inc. v. White, 2000 Cal. LEXIS 3536 (Cal. Apr. 12, 2000). Although one federal district court found inevitable disclosure part of California trade secrets law, Maxxim Medical, Inc. v. Michelson, 51 F. Supp. 2d 773 (S.D. Tex. 1999), rev'd without opinion, 182 F.3d 915 (5th Cir. 1999), the federal courts generally ruled that inevitable disclosure was not the law in California. E.g., Danjaq, LLC v. Sony Corp., No. CV 97-8414-ER, 1999 WL 317629, at*1 n.1 (C.D. Cal. Mar. 11, 1999) ("PepsiCo is not the law of the State of California or the Ninth Circuit.").
}

${ }^{302} 125$ Cal. Rptr. 2d 277 (Cal. Ct. App. 2002).

${ }^{303} I d$. at 281 .

${ }^{304} I d$. 
between Schlage and Home Depot on June 5. ${ }^{305}$ Litigation ensued thereafter, with Schlage claiming a misappropriation of trade secrets. ${ }^{306}$

The Whyte court joined what it characterized as a "growing band of cases" rejecting inevitable disclosure, cases that it believed "correctly balanced competing public policies of employee mobility and protection of trade secrets." ${ }^{307}$ California's policy of protecting employee mobility was not viewed as entirely inconsistent with the inevitable disclosure doctrine, because a narrow nonsolicitation agreement (for example, restraining Whyte from selling to Home Dept) might be consistent with California's restrictive employee noncompete statute. ${ }^{308}$ What the court found pernicious was the "after-the-fact" nature of the covenant not to compete imposed under the doctrine, a covenant imposed without the employee's consent. ${ }^{309}$ The court argued that the doctrine has the effect of converting a confidentiality agreement into a noncompete covenant:

The doctrine of inevitable disclosure thus rewrites the employment agreement and 'such retroactive alterations distort the terms of the employment relationship and upset the balance which courts have attempted to achieve in construing non-compete agreements.' ... As a result of the inevitable disclosure doctrine, the employer obtains the benefit of a contractual provision it did not pay for, while the employee is bound by a court-imposed contract provision with no opportunity to negotiate terms or consideration. ${ }^{310}$

The Whyte court was particularly influenced by a federal district court opinion from New York. ${ }^{311}$ In EarthWeb, Inc. v. Schlack, ${ }^{312}$ the court rejected the application of the doctrine to prevent a high-level executive of an Internet publishing company from assuming a similar position with a new competitor. ${ }^{313}$ In resolving the inevitable disclosure claim, the court

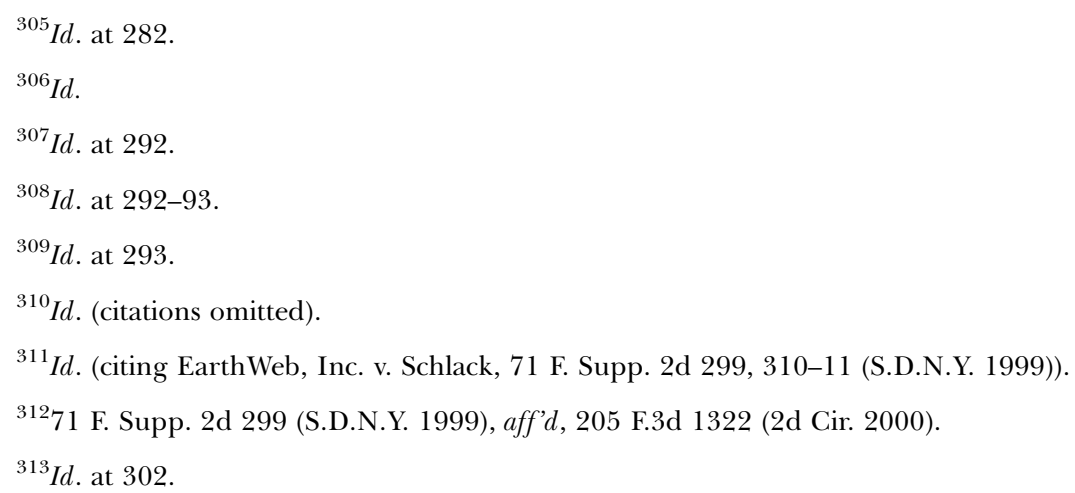


provided the strongest judicial critique of the doctrine to date. The court recognized that the inevitable disclosure doctrine was not new-courts had restrained employees under noncompete agreements where employees possessed sensitive information that they would inevitably use in competing with their former employers. ${ }^{314}$ But it viewed PepsiCo and the cases adopting it as extending the doctrine beyond the noncompete context. $^{315}$ Although this extension was not problematic where there was evidence of actual misappropriation of trade secrets by competing former employees, it presented serious risks to the policies underlying employee noncompete law in situations in which the employees had not signed binding noncompete agreements. ${ }^{316}$ The court also believed that this doctrine would have in terrorem effects on employees and upset the delicate balance of rights under noncompete law. ${ }^{317}$ Finally, unlike the noncompete context, courts are left without any "frame of reference" to judge reasonableness; rather, the courts must decide questions of "inevitability," a nebulous concept that would spawn litigation. ${ }^{318}$ Predictability in the employment relationship is better served when the parties negotiate noncompete terms. ${ }^{319}$ Thus, the EarthWeb court concluded that the doctrine "treads an exceedingly narrow path through judicially disfavored territory," one that should be taken in only the "rarest of cases.",320

\footnotetext{
${ }^{314}$ Id. at 309 .

${ }^{315} \mathrm{Id}$. at $309-10$.

${ }^{316}$ Id. at 310 .

${ }^{317}$ The court explained:
}

Among these risks is the imperceptible shift in bargaining power that necessarily occurs upon the commencement of an employment relationship marked by the execution of a confidentiality agreement. When that relationship eventually ends, the parties' confidentiality agreement may be wielded as a restrictive covenant, depending on how the employer views the new job its former employee has accepted. This can be a powerful weapon in the hands of an employer; the risk of litigation alone may have a chilling effect on the employee.

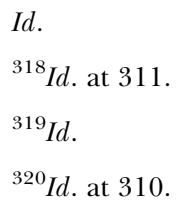


EarthWeb is significant for several reasons. First, it provides a powerful argument against the inevitable disclosure doctrine, a critique that is founded on solid policy and practical concerns. Second, it is part of a growing judicial hostility toward the inevitable disclosure doctrine. ${ }^{321}$ Although EarthWeb did not repudiate the doctrine altogether, its policy critique supports a narrow reading of PepsiCo and justifies limiting the application of inevitable disclosure to "rare cases." "222 Finally, EarthWeb's influence in New York, an important jurisdiction, already has been felt. Several state and federal courts have embraced the EarthWeb rationale and limited the application of the doctrine in New York. ${ }^{323}$ Prior to EarthWeb, New York courts had been far more receptive to the inevitable disclosure doctrine. ${ }^{324}$

The EarthWeb critique has also influenced other courts outside of New York. The 2004 Maryland Court of Appeals decision, LeJeune v. Coin Acceptors, Inc., ${ }^{325}$ rejected the inevitable disclosure doctrine relying heavily on EarthWeb and Whyte. LeJeune is one of only a handful of inevitable disclosure cases to be decided by a state's highest court. ${ }^{326}$ Most of the case law in support of inevitable disclosure has been at the federal level. LeJeune is important because it may signal that state courts are going to be more reluctant to embrace the PepsiCo formulation than the federal courts. ${ }^{327}$

\footnotetext{
${ }^{321}$ Whyte, 125 Cal. Rptr. 2d at 292 (citing EarthWeb among others as "[a] smaller but growing band of cases [that] rejects the inevitable disclosure doctrine").

${ }^{322} I d$.

${ }^{323}$ See, e.g., PSC, Inc. v. Reiss, 111 F. Supp. 2d 252, 256-59 (W.D.N.Y. 2000) (relying on EarthWeb to apply inevitable disclosure doctrine strictly and deny request for injunction); Marietta Corp. v. Fairhurst, 754 N.Y.S.2d 62, 64-65, 67 (N.Y. App. Div. 2003) (noting, with reference to EarthWeb, that inevitable disclosure is disfavored and reversing grant of injunction based on inevitable disclosure).

${ }^{324}$ E.g., Lumex, Inc. v. Highsmith, 919 F. Supp. 624, 631 (E.D.N.Y. 1996) (finding inevitable disclosure).

${ }^{325} 849$ A.2d 451 (Md. 2004).

${ }^{326}$ The Arkansas Supreme Court decision in Cardinal Freight Carriers, Inc. v. J.B. Hunt Transport Services, Inc., 987 S.W.2d 642 (Ark. 1999), is the only state supreme court opinion to have expressly adopted inevitable disclosure. Id. at 646-47.

${ }^{327}$ Other state court opinions have rejected the PepsiCo formulation of inevitable disclosure. E.g., Gov't Tech. Servs., Inc. v. Intellisys Tech. Corp., No. 160265, 1999 WL 1499548 (Va. Cir. Ct. Oct. 20, 1999). The North Carolina Court of Appeals also rejected the PepsiCo doctrine in
} 
From a factual perspective, LeJeune provided the Maryland court with a fairly compelling case for the application of the inevitable disclosure doctrine. Like PepsiCo, the lawsuit involved two direct competitors in the coin machine market, Coin Acceptors, Inc. (Coinco), and Mars Electronics, Inc. (Mars). ${ }^{328}$ LeJeune was an Area Account Manager for Coinco, responsible for the vending market in Delaware, Maryland, Virginia, and West Virginia. He also was involved with marketing a new bill acceptor machine to the amusement market in early 2003. He was exposed to sensitive business information and was knowledgeable about Coinco's marketing and pricing strategies. ${ }^{329} \mathrm{He}$ left Coinco in the summer of 2003 to work for Mars as the Amusement OEM (Original Equipment Manufacturer) Manager. ${ }^{330}$ Prior to leaving, he copied from his laptop numerous Coinco documents containing information about Coinco's budgeting, manufacturing costs, profit margins, and pricing. In addition, he retained hard copies of documents containing other sensitive information, including technical specifications on Coinco's new bill acceptor machine. ${ }^{331}$

The LeJeune court noted that pre-UTSA cases on inevitable disclosure had involved "extraordinary situations in which a company tried to guard the secrecy of some technology that had propelled the company into industry leadership." ${ }^{332}$ It further observed that PepsiCo was the "most notable" inevitable disclosure case under the UTSA, but that the theory itself is the subject of "considerable disagreement." 333 In resolving the issue in Maryland, the court found the reasoning of Whyte and EarthWeb

Analog Devices, Inc. v. Michalski, 579 S.E.2d 449 (N.C. Ct. App. 2003). The court refused to follow the lead of the federal court in Merck छ Co. Inc. v. Lyon, 941 F. Supp. 1443 (M.D. N.C. 1996). Although Lyon had embraced the PepsiCo approach, the Analog Devices court held that an injunction restraining employment would only be issued if there was a showing of "bad faith, underhanded dealing, or inferred misappropriation (justified by circumstances tending to show the new employer plainly lacks comparable technology)." 579 S.E.2d at 455 n.4. In so ruling, the Analog Devices court did not even discuss the federal court decision in Lyon.

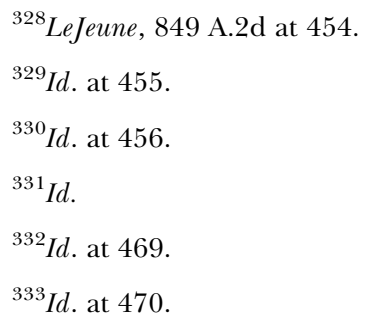


persuasive. It agreed with the Whyte court that the doctrine creates a de facto noncompete agreement that is inconsistent with long-standing policies in Maryland law favoring employee mobility. ${ }^{334}$ Also, the doctrine has the effect of permitting an inference of trade secret disclosure merely because an employee was privy to secret information. Adoption of the theory also would tend to permit a court to infer some inevitable disclosure of trade secrets merely from an individual's exposure to them. ${ }^{335}$

Courts are rightly concerned with the detrimental impact that the inevitable disclosure doctrine has on the delicate policy balance between the employer's interest in information protection and the employee's competing interest in free mobility. Because the PepsiCo formulation upsets that delicate balance, most courts will probably continue to adopt standards for inevitable disclosure that more closely resemble the common law.

\section{Public Policy and Employee Mobility: THE NEW EMPLOYMENT RELATIONSHIP AND THE INFORMATION-AGE ECONOMY}

Recent noncompete cases reveal a distinct trend heightening the judicial scrutiny of employee agreements not to compete, ${ }^{336}$ a trend that is mirrored in the most recent opinions on the inevitable disclosure doctrine. ${ }^{337}$ It has become more difficult for employers to enforce covenants not to compete and this new legal environment presents challenges to drafting enforceable noncompete agreements. These recent developments signal a shift to a strict approach to such restrictive covenants founded on a dominant policy concern for the protection of employee mobility.

The heightened scrutiny of employee noncompete agreements reflects some of the fundamental changes taking place in the economy and in the workplace. Both management and law scholars have commented

\footnotetext{
${ }^{334} I d$ at 471 ("To recognize 'inevitable disclosure' in this case would allow Coinco the benefit of influencing LeJeune's employment relationship with Mars even though Coinco chose not to negotiate a restrictive covenant or confidentiality agreement with LeJeune.").

${ }^{335}$ But see infra note 436 and accompanying text, which notes that most courts have not endorsed such an inference.

${ }^{336}$ See supra Part V.

${ }^{337}$ See supra Part VI.C.
} 
on the changing nature of the employment relationship, particularly the movement away from the traditional long-term employment relationship typical in the industrial age. ${ }^{338}$ Scholars also have commented on the benefits of information sharing and employee mobility in the informationage economy. ${ }^{339}$ These interrelated changes have significant implications for the evolving law of employee noncompete agreements.

\section{A. The New Employment Relationship}

A new employment relationship has emerged from the restructuring of the American economy that began in the 1980 s. ${ }^{340}$ The paradigm of the preinformation-age employment relationship is rapidly dying. ${ }^{341}$ The industrial employment relationship was characterized by long-term commitments from employers and employees, advancement within a firm, and job security. ${ }^{342}$ This relationship was beneficial to businesses in the industrial economy because it facilitated long-term business planning and allowed firms to invest heavily in employee training. ${ }^{343}$ Also, it created an implied quid pro quo - employers guaranteeing employment and the potential for advancement within the firm in exchange for employee loyalty and commitment. $^{344}$ This psychological contract enhanced productivity in the workplace. Finally, promotion within the organization provided the means for employees to advance in their careers, and this was facilitated by tiered business structures with multiple layers of management. ${ }^{345}$

\footnotetext{
${ }^{338}$ See, e.g., Peter Capelli, The New Deal at Work, Managing the Market-Driven Workforce (1999); Rachel S. Arnow-Richman, Bargaining for Loyalty in the Information Age: A Reconsideration of the Role of Substantive Fairness in Enforcing Employee Noncompetes, 80 OR. L. REv. 1163 (2001); Katherine V. W. Stone, Knowledge at Work: Disputes over the Ownership of Human Capital in the Changing Workplace, 34 ConN. L. REv. 721 (2002).

${ }^{339}$ E.g., Bishara, supra note 23; Gilson, supra note 43; Alan Hyde, The Wealth of Shared Information: Silicon Valley's High-Velocity Labor Market, Endogenous Economic Growth, and the Law of Trade Secrets (Sept. 1998), http://andromeda.rutgers.edu/ hyde/WEALTH.htm.

${ }^{340}$ Capelli, supra note 338 , at 4-5.

${ }^{341}$ Stone, supra note 338 , at 725-29.

${ }^{342} I d$. at 725 .

${ }^{343}$ Capelli, supra note 338 , at 63-64.

${ }^{344}$ Stone, supra note 338 , at 725 .

${ }^{345}$ Id
} 
Employee noncompete agreements were well suited to the old employment relationship, because restrictive covenants have the effect of stifling employee mobility.

The new employment relationship substitutes external market forces for the internal labor market of the industrial age. ${ }^{346}$ Its primary characteristics are employee mobility, a lack of job security, and limited loyalty by either employees or employers. Employers ensure the viability of the firm by maintaining its competitiveness, which requires rapid changes in strategies and plans because of short time horizons for product and service developments. ${ }^{347}$ Competition at home and abroad has caused firms to become more cost conscious. Globalization and competition also have forced firms to downsize and restructure their business organizations. ${ }^{348}$ Firms also must be responsive to external financial markets. ${ }^{349}$ Maintaining the profitability and standing of the firm with investors often requires drastic cost-cutting measures when the firm's profits are not as expected in the market. ${ }^{350}$ In this environment, massive layoffs have become commonplace and employees are becoming used to this environment of job insecurity.

The new employment relationship is more uncertain and flexible than the industrial model. A new psychological contract is emerging that reflects the realities of the new workplace. ${ }^{351}$ Under the new implicit quid pro quo, employers do not make a long-term commitment of employment and job security in exchange for the loyalty of the employee. ${ }^{352}$ Rather, if the employer makes any implied commitment at all, it is that employment will provide employees with the skills and experiences necessary to make them competitive in the market. Employability, not employment, is what the

\footnotetext{
${ }^{346}$ CAPELli, supra note 338 , at $17-48$.

${ }^{347} I d$. at $5,49-68$.

${ }^{348}$ Stone, supra note 338 , at 729 .

${ }^{349}$ CAPELLI, supra note 338, at 81-85 (noting shareholder pressure on firms).

${ }^{350} I d$. at 80 (noting positive investor reaction to slashing jobs at Xerox, a very well-run company).

${ }^{351}$ Stone, supra note 338 , at $729-31$.

${ }^{352}$ See Marleen A. O'Connor, Restructuring the Corporation's Nexus of Contracts: Recognizing a Fiduciary Duty to Protect Displaced Workers, 69 N.C. L. Rev. 1189, 1205-07 (1991) (explaining longterm relationships between employees and employers).
} 
employer implicitly offers in exchange for the employee's efforts and productivity. ${ }^{353}$

Scholars have argued that employee noncompete agreements are a necessary means to protect a firm's investment in its employees. ${ }^{354}$ Professors Paul Rubin and Peter Shedd claim that some forms of employee training may result in employees acquiring firm-specific knowledge, and the costs of that training cannot be shifted to the employee through wage adjustments. $^{355}$ Noncompete agreements are necessary, they argue, to provide firms with some protection for the costs incurred in providing sensitive human capital, because competitors could reap the benefits of that information by hiring away employees of the firm. ${ }^{356}$

But given the new employment relationship, the underlying assumptions about protecting human capital development have been questioned. It has been argued that employees should be given "broad rights to acquire, retain, and deploy their human capital" under the new psychological contract in which employers offer "employability" rather than employment. ${ }^{357}$ This is consistent with the implicit understanding between the parties as to the ownership of human capital. Alternatives to the enforcement of noncompete agreements also exist in those situations where specialized training is provided, including training repayment agreements. ${ }^{358}$

\footnotetext{
${ }^{353}$ CAPELLI, supra note 338, at 29-30 ("Most of the new deals refer to this as the 'employability' concept: We cannot offer you security with our company, but we can help you to secure skills that will keep you employable, that will lead to some security in the labor market by helping you find other jobs."); Rosabeth Moss Kanter, Rosabeth Moss Kanter on the Frontiers of Management 190-94 (1997); Mark V. Roehling et al., The Nature of the New Employment Relationship(s): A Content Analysis of the Practitioner and Academic Literatures, 39 Hum. Resource MGмт. 305, 312-13 (2000) (discussing the use of the term employability in practice and scholarship and distinguishing between "internal employability" and "external employability").

${ }^{354}$ See, e.g., Maureen B. Callahan, Post-Employment Restraint Agreements: A Reassessment, 52 U. Chi. L. Rev. 703, 716-18 (1985) (arguing that noncompete agreements are the employer's only means of protecting its investment in human capital); Paul H. Rubin \& Peter Shedd, Human Capital and Covenants Not to Compete, 10 J. Legal Stud. 93, 96-99 (1981) (arguing that noncompete agreements are necessary when, for example, "general training" costs are too high for employees to self-finance).

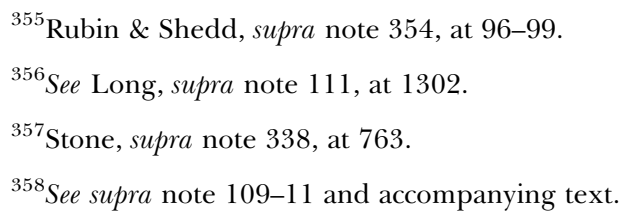


Overall, restrictive covenants seem ill suited to the emerging employment relationship where job insecurity and employee mobility are key features. Rigorous enforcement of employee noncompete agreements also would appear to be inconsistent with the implied commitment of employability under the new psychological contract. ${ }^{359}$

\section{B. Information Sharing and Technological Innovation}

There is considerable debate about the economics of enforcing noncompete agreements to protect secret business information, particularly in the emerging high-technology economy. The traditional view was that the protection of trade secrets under noncompete law was necessary to provide firms with the incentive to engage in expensive R\&D activities. ${ }^{360}$ Those R\&D activities lead to innovations in products and services and thereby make firms more competitive. Without legal protection for such new innovations, firms would be unwilling to make the same level of R\&D expenditures, because competitors would be able to gain the knowledge underlying those innovations by hiring away employees of the firm. ${ }^{361}$ Information sharing in this context, therefore, causes negative economic effects by reducing the level of $R \& D$ that all firms undertake or by increasing the costs of protecting the knowledge that firms develop.

Even those who espouse the traditional economic view of trade secret protection under employee noncompete agreements must recognize the limitations of the classical model. First, employee noncompete agreements can be anticompetitive under certain circumstances, and employers may engage in attempts to unfairly restrict competition. If protected information or specialized training is not involved, employee noncompete agreements may be a means by which firms with market power maintain their position by restricting the flow of information or eliminating the potential for new market entrants. ${ }^{362}$ Second, enforcement of

\footnotetext{
${ }^{359}$ Stone, supra note 338 , at 738 (arguing that judicial approaches to noncompete agreements that favor employers are "out of step with the new employment relationship").

${ }^{360}$ See, e.g., Callahan, supra note 354, at 715 ("To the extent that inventors are prevented from reaping the benefits of the information they develop, they are discouraged from engaging in costly research and development, and competition will suffer because fewer products will be produced.”).

${ }^{361}$ See id.

${ }^{362} I d$. at $716-18$.
} 
employee noncompete agreements causes a misallocation of scarce human resources. From a macroeconomic standpoint, human resources are not put to their most efficient uses when noncompete agreements force employees to work outside of their professions or fields of expertise. ${ }^{363}$ Third, protection of secret information under intellectual property law is never absolute. Thus, the important public policy question is the balance between information sharing and information protection. For example, we allow the discovery and exploitation of trade secret information through some means, such as reverse engineering. ${ }^{364}$ Under the trade secret regime, the law balances the negative and positive effects of protecting information. Information sharing is often essential for healthy competition and a proper functioning of the market; ${ }^{365}$ yet some level of information protection is also critical for innovation and technological advancement. Just as the extent to which we allow copying and imitation of products and services reflects this balance, so does the extent to which we allow employees to engage in postemployment competition.

Some commentators have challenged the classical economic view of noncompete agreements, asserting that restrictive covenants conflict with the need for rapid knowledge transfers and innovation in a high-technology environment. ${ }^{366}$ Scholars have claimed that the enforcement of employee noncompete agreements may actually reduce technological advancement and economic growth. ${ }^{367}$ These arguments are supported by the groundbreaking work of Professor AnnaLee Saxenian, who studied the rise of Silicon Valley in the high-technology sector during the

\footnotetext{
${ }^{363}$ See Blake, supra note 23, at 627 (noncompetes agreements may "clog the market's channeling of manpower to employments in which its productivity is greatest").

${ }^{364}$ E.g., Kewanee Oil Co. v. Bicron Corp., 416 U.S. 470, 490 (1974) (“[T]rade secret law does not forbid the discovery of the trade secret by fair and honest means, $e$. $g$., independent creation or reverse engineering."); Chicago Lock Co. v. Fanberg, 676 F.2d 400, 405 (9th Cir. 1982) ("A [consumer]'s own reverse-engineering of [a product] ... is an example of the independent invention and reverse engineering expressly allowed by trade secret doctrine.").

${ }^{365}$ Callahan, supra note 354 , at 715 (conceding that "competition by way of product imitation and improvement requires the free flow of information").

${ }^{366}$ E.g., Gilson, supra note 43; Hyde, supra note 339.

${ }^{367}$ Employee noncompete agreement "present a barrier to the second-stage agglomeration economy that sustains a high technology district." Gilson, supra note 43, at 607. See also Chris Montville, Reforming The Law Of Proprietary Information, 56 Duke L.J. 1159, 1192 (2007).
} 
1980s. ${ }^{368}$ As Saxenian's study documents, Silicon Valley experienced far greater economic growth than the Route 128 region of Massachusetts during this period, and this occurred despite Route 128's strong position in the electronics and computer industries in the 1970s. ${ }^{369}$ Saxenian attributes Silicon Valley's relative success to the differing cultures and structures of the two industrial regions. ${ }^{370}$ Silicon Valley was dominated by small firms with frequent employee crossover and a culture of information sharing. ${ }^{371}$ Route 128 was dominated by large integrated firms with minimal employee turnover and an environment of secrecy. ${ }^{372}$ Professor Saxenian's study indicates that the Valley's culture of relatively free employee mobility, information sharing, and entrepreneurial activity created the booming industrial district. ${ }^{373}$ Her study further indicates that the reason Silicon Valley surpassed Route 128 during this period of time was due to the knowledge spillovers that occurred as employees changed firms and started new businesses. ${ }^{374}$ This culture of information sharing drove the rapid development of new technologies and had positive economic effects on the region. ${ }^{375}$

Building on the economic record of Silicon Valley, Professor Ronald Gilson has posited that it was California's restrictive approach to employee noncompete agreements that provided the legal infrastructure supporting

\footnotetext{
${ }^{368}$ E.g., Annalee Saxenian, Regional Advantage: Culture and Competition in Silicon Valley AND Route 128 (1994).

${ }^{369}$ See Christine M. O'Malley, Note, Covenants Not to Compete in the Massachusetts Hi-Tech Industry: Assessing the Need for a Legislative Solution, 79 B.U. L. Rev. 1215, 1224 (1999) (citing SAXENIAN, supra note 368 , at 9).

${ }^{370}$ SaXenian, supra note 368 , at $2-4$ \& $29-104$.

${ }^{371} I d$. at $2-3$ \& $29-57$.

${ }^{372} I d$. at $3-4 \& 59-82$.

${ }^{373} I d$. at $161-62$.

${ }^{374}$ Professor Gilson explains this portion of Saxenian's work as follows: "In Saxenian's account, knowledge spillovers facilitated by the mobility of employees and the resulting bias against vertical integration turned the entire industrial district into an engine of continuous innovation, thereby transcending the life cycle of any single product." Gilson, supra note 43, at 591. See also Hyde, supra note 339.

${ }^{375}$ Gilson, supra note 43 , at 586 ("These knowledge spillovers supercharge the innovative capacity of the district with renewed agglomeration economies, facilitating the development of new technologies that create a new industrial life cycle.").
} 
the economic growth of the region. ${ }^{376}$ That is, the culture of free mobility of labor was a result of the legal hostility to employee noncompete agreements in the state. ${ }^{377}$ In making that claim, Gilson noted the differences between the California and Massachusetts approach to employee noncompete agreements ${ }^{378}$ : Massachusetts follows the common law reasonableness standard, which results in the enforcement of employee noncompete agreements under some circumstances. ${ }^{379}$ Because California prohibits almost all employee noncompete agreements, ${ }^{380}$ employee mobility is restricted to a far greater extent in Massachusetts than in California. To the extent that the difference between the two region's economic performances is attributable to California's restrictive approach to employee noncompete agreements, as Gilson contends, the success of Silicon Valley provides some support for the argument that restricting employee noncompete agreements can actually stimulate technological innovation and economic growth.

A recent empirical study tested the contentions about the Silicon Valley experience by examining data on employee mobility in Silicon Valley and other cities. ${ }^{381}$ The authors found strong evidence that employees working in the computer industry in Silicon Valley have higher rates of job mobility than in other cities with information-technology (IT) clusters. ${ }^{382}$ This finding provides support for the arguments concerning

\footnotetext{
${ }^{376}$ See id. at 578 \& 609 ("Silicon Valley's legal infrastructure, in the form of Business and Profession Code section 16600's prohibition of covenants not to compete, provided a pole around which Silicon Valley's characteristic business culture and structure precipitated."). See also Hyde, supra note 339; Hanna Bui-Eve, Note, To Hire or Not to Hire: What Silicon Valley Companies Should Know about Hiring Competitors' Employees, 48 Hastings L.J. 981, 982-83 (1997). But see Jason S. Wood, A Comparison of the Enforceability of Covenants Not to Compete and Recent Economic Histories of Four High Technology Regions, 5 VA. J.L. \& TECH. 14 (2000), http:// www.vjolt.net/vol5/issue3/v5i3a14-Wood.html (finding no correlation between a region's success in the high-tech sector and differences in the enforceability of employee noncompete agreements).

${ }^{377}$ Gilson, supra note 43 , at 603 .

${ }^{378} I d$. at $603-08$.

${ }^{379}$ See, e.g., Boulanger v. Dunkin' Donuts Inc., 815 N.E.2d 572, 574 (Mass. 2004) (discussing covenants not to compete in a franchise context).

${ }^{380}$ See supra notes $61-62$ and accompanying text.

${ }^{381}$ Bruce Fallick et al., Job Hopping in Silicon Valley: The Micro-Foundations of a High Technology Cluster, Oct. 23, 2003, http://www.nber.org/ confer/2004/ents04/fallick.pdf.

${ }^{382} I d$. at 29.
} 
knowledge spillovers and employee turnover in that region. Also, the authors found some evidence of a "California effect," because hypermobility was found in IT clusters in other California cities. ${ }^{383}$ This provides some support for the proposition that California's restrictive policies on employee noncompete agreements may have played a role in the Silicon Valley success story, although the authors noted as a caveat that they had no direct evidence that the high mobility was due to the California policy on noncompete agreements as opposed to other factors, such as culture. ${ }^{384}$

Another empirical study found that laws restricting covenants not to compete can increase innovation. ${ }^{385}$ However, the beneficial effects are most likely to be realized in industries where small firms have an innovative advantage over large firms. ${ }^{386}$ Thus, the study suggests that the economic effects of noncompete agreements differ depending on the particular industry and firm structure, but restrictions on such agreements may support economic growth, particularly where there are R\&D spillover effects. ${ }^{387}$ The study further suggests that the law should focus more on the effects of employee noncompete agreements on competition than on the traditional factors under the common law reasonableness approach. ${ }^{388}$

The studies of the economics of employee noncompete agreements are not conclusive, but they provide evidence of some positive economic benefits from employee mobility and information sharing, at least in certain fields. What economists and others have observed is likely the result of some fundamental changes in the nature of a modern information-based economy. In the new economy, innovation may actually be facilitated by "information flow between participants in the innovative process," particularly in knowledge-intensive industries where much of the

\footnotetext{
${ }^{383} I d$.

${ }^{384} I d$. at 30 .

${ }^{385}$ Deborah M. Weiss, Entrepreneurial Employees, http://www.utexas.edu/law/news/colloquium/ papers/Weisspaper.doc at 2 (last visited Oct. 4, 2007) ("“N]onenforcement of noncompetes stimulates economic growth in industries where innovation is dominated by small firms.").

${ }^{386} I d$. at 17 ("If laws restricting noncompetes are ever to have a positive effect, they should have one in industries in which the small firms that employees might start have an innovative advantage.").

${ }^{387}$ See id. at 34 ("The analysis in the preceding Sections suggests that restricting noncompetes can increase output if the workforce is heterogeneous or R\&D has spillover effects.").

${ }^{388}$ See id. at $43-44$.
} 
knowledge is undeveloped ideas. ${ }^{389}$ Also, there may be a significant economic impact from new firms developing unrealized opportunities in such knowledge-intensive environments. ${ }^{390}$ The existence of knowledge spillovers may not be indicative of employees "stealing" proprietary information to unfairly compete as much as it is evidence of employees engaged in entrepreneurial activity by capitalizing on new ideas and innovations that have not been commercialized by their employers. ${ }^{391}$ If so, such knowledge spillovers and entrepreneurial activity may be critical to economic growth in the new economy.

\section{EMPLOYEE NONCOMPETE LAW: A DOCTRINAL ANALysis AND Alternative Policy FramewOrK}

The trend of recent decisions heightening the judicial scrutiny of employee noncompete agreements is supported by the changing nature of the employment relationship and bolstered by evidence as to the positive economic effects of restricting employee noncompete agreements. To some extent, the law of employee noncompete agreements can be adapted to reflect these new market realities and to protect employee mobility. This is particularly the case with respect to the protection of the goodwill interest under noncompete agreements. We believe, however, that in the context of noncompete agreements and trade secrets, an entirely new policy approach is necessary.

A. Noncompete Agreements and the Goodwill Interest: Adapting Noncompete Law to Protect Employee Mobility

The rationale for the protection of goodwill under noncompete agreements is distinctly different from that for trade secrets. ${ }^{392}$ Any approach to the law of employee noncompete agreements should recognize this

\footnotetext{
${ }^{389}$ Thomas Mandeville, Understanding Novelty: Information, Technological Change, and the Patent System 10 (1996).

${ }^{390}$ David B. Audretsch \& Max Keilbach, The Knowledge Spillover Theory of Entrepreneurship (Dec. 2004) (unpublished manuscript, on file with authors).

${ }^{391} I d$.

${ }^{392}$ Compare supra notes 35-37 and accompanying text with supra notes 38-44 and accompanying text.
} 
distinction. In terms of the goodwill interest, employee noncompete agreements directly protect the employer's interest in customer relationships. ${ }^{393}$ That is, by not being allowed to compete, the employee is prevented from exploiting the relationships he or she developed working for the employer. So, for example, a nonsolicitation agreement prevents a former employee from contacting clients or customers of the former employer on the theory that such relationships are part of the goodwill owned by the employer. ${ }^{394}$ Moreover, without contractual restrictions on postemployment competition, former employees would be free to take advantage of those relationships, ${ }^{395}$ as any duty of loyalty to their former employer has ended with the termination of the agency relationship. ${ }^{396}$ Thus, noncompete agreements directly prevent this misappropriation of goodwill and thereby prevent a form of unfair competition. ${ }^{397}$

Carefully tailored noncompete agreements would allow employees to compete but would not permit employees to compete unfairly by misappropriating their employers' goodwill. The recent decisions in BDO Seidman ${ }^{398}$ Freiburger, ${ }^{399}$ and Merrimack Valley ${ }^{400}$ represent the courts'

\footnotetext{
${ }^{393}$ See, e.g., Cohoon v. Fin. Plans \& Strategies, Inc., 760 N.E.2d 190, 195 (Ind. Ct. App. 2001) (stating that "an employer is entitled to contract to protect the good will of the business," but stating that "secret or confidential information" is an element of this goodwill); Boldt Mach. \& Tools, Inc. v. Wallace, 366 A.2d 902, 906 (Pa. 1976) (“[A]n employer has a protectible interest in the customer goodwill developed by its employees." (citations omitted)).
}

${ }^{394}$ Montville, supra note 367 , at 1174 .

${ }^{395}$ Blake, supra note 23 , at 655 (courts have "generally agreed that in the absence of an express contract, [an employee] may not be restrained from competing with his former employer nor from soliciting his customers.").

${ }^{396}$ Restatement (Third) of Agency $\S 8.01 \mathrm{cmt}$. c (2006) (“An agent's fiduciary duty to a principal is generally coterminous with the duration of the agency relationship.").

${ }^{397}$ See, e.g.,. Manpower of Guilford County, Inc. v. Hedgecock, 257 S.E.2d 109, 114 (N.C. App., 1979) ("When the nature of employment such as in the instant case is such that the employee has personal contact with the patrons and customers of an employer, or where the employee acquires valuable information as to the nature and character of the business and the names of patrons or customers, thereby enabling him to take advantage of such knowledge and to compete unfairly with a former employer, equity may be interposed to prevent the breach of a covenant not to compete which is reasonable as to time and territory.").

${ }^{398} 712$ N.E.2d 1220 (N.Y. 1999). See supra notes 152-61 and accompanying text discussing the case.

${ }^{399} 111$ P.3d 100 (Idaho 2005). See supra notes 185-99 and accompanying text discussing the case. ${ }^{400} 876$ A.2d 757 (N.H. 2005). See supra notes 200-9 and accompanying text discussing the case. 
attempts to ensure that employee noncompete agreements are not overbroad. This can be achieved under the prevailing common law reasonableness standard in one of two ways. First, as in BDO Seidman, the courts can narrowly define the employer's interest in goodwill. BDO Seidman recognized a legitimate interest in protecting only those clients acquired by the employee during the course of his employment. ${ }^{401}$ Any noncompete agreement that attempted to prevent the employee from servicing clients with whom the employee had no relationship at BDO Seidman was fatally overbroad. ${ }^{402}$ Merrimack Valley's "sphere of customer influence" is another way to define the protectable interest in goodwill. ${ }^{403}$ By narrowly circumscribing that protectable interest, courts can ensure that noncompete agreements are carefully tailored to prevent only unfair competition.

Alternatively, the courts can restrict the scope of employee noncompete agreements to ensure that they are no broader than necessary to protect the employer's goodwill interest. ${ }^{404}$ The rule that an employee noncompete agreement can only restrict a former employee from soliciting clients with whom the employee had contacts reaches the same result; however, its focus is on the breadth of the noncompete agreement rather than the scope of the protectable interest. ${ }^{405}$ Regardless of the doctrinal means by which the result is achieved, the common law reasonableness standard can be adjusted in such a way as to prevent only those forms of employee competition that exploit the former employer's protectable goodwill interest.

The law also needs to ensure that employers do not overreach, drafting overbroad noncompete agreements with the expectation that, if challenged, the court will reform the agreement. The movement to a rule of reformation has some strong policy justifications. First, the rule is more flexible than the blue pencil doctrine because the courts are not limited to severing separate and distinct covenants. ${ }^{406}$ Second, reformation allows

\footnotetext{
${ }^{401} 712$ N.E.2d at 1225 .

${ }^{402}$ Id

${ }^{403} 876$ A.2d at $763-65$.

${ }^{404}$ See supra Part V.B.

${ }^{405}$ See id.

${ }^{406}$ See supra notes $117-23$ and accompanying text. See also Robert W. Emerson, Franchising Covenants against Competition, 80 IowA L. Rev. 1049, 1055 n.20 (1995).
} 
partial enforcement of a noncompete agreement if the actual postemployment competition is unfair even though the terms of the agreement are overbroad. ${ }^{407}$ From an equitable standpoint, the employee's position in such situations is not defensible, and the employer's legitimate interests are at risk. The downside of the rule of reformation is that it may encourage employers to overreach because there is no penalty for requiring employees to sign an overbroad agreement. At the very least, the rule does not discourage employers from broadly drafting their noncompete agreements. The requirement of good faith is designed to act as a disincentive, ${ }^{408}$ but it does not in practice provide a sufficient check on employer overreaching. Because of this drawback of reformation, the more restrictive blue pencil doctrine adopted in Valley Medical Specialists ${ }^{409}$ has some appeal.

Freiburger and Merrimack Valley demonstrate, however, that the rule of reformation can be modified to provide a more potent disincentive. ${ }^{410}$ Courts should limit the power of reformation when enforcement of the overbroad agreement would be unfair because of the conduct of the employer. Freiburger focuses on the substance of the noncompete agreement and the degree to which a covenant must be modified to render it reasonable. If the covenant is facially overbroad, requiring substantial modification by the courts, Freiburger does not permit reformation. ${ }^{411}$ Merrimack Valley focuses on the procedural fairness of partially enforcing an overbroad agreement through reformation. Factors indicating a lack of good faith from a procedural standpoint include whether the agreement was discussed during negotiations and whether the employer used unfair bargaining power to secure the agreement. ${ }^{412}$ Ultimately, a good faith "fairness" standard that has some teeth to it emerges from these cases. If adopted, such a standard would still allow reformation, but would require a higher level of fair dealing between the parties for the courts to exercise their equitable powers to grant reformation.

\footnotetext{
${ }^{407} 5$ Williston on Contracts § 2:3 (14th ed. 1993).

${ }^{408}$ See supra notes $125-26$ and accompanying text for a discussion of the good faith standard. ${ }^{409} 982$ P.2d 1277, 1286 (Ariz. 1999).

${ }^{410}$ See supra notes $185-96$ \& 200-09 and accompanying text.

${ }^{411} 111$ P.3d 100, 107-08 (Idaho 2005).

${ }^{412} 876$ A.2d at $764-65$.
} 
Overall, the emerging law of employee noncompete agreements provides rules and doctrines to ensure that noncompete covenants are not overbroad in the protection of the employer's interest in goodwill. In this context, the law can be adjusted to reflect the heightened concern for employee mobility.

\section{B. Trade Secrets and Noncompete Agreements}

In contrast to noncompete agreements designed for the protection of goodwill, agreements designed to protect trade secrets do not directly prevent trade secret misappropriation or forestall unfair competition by competing former employees. An employee who starts a new business or goes to work for a competitor without using or disclosing the former employer's trade secrets is not engaged in unfair competition. The employer's trade secret interest is only jeopardized if the employee exploits this information for his own commercial advantage or for the advantage of his new employer. A noncompete covenant in this context is designed as a prophylactic measure to protect against the potential of a trade secret misappropriation. But, as with all preventative legal measures, the noncompete instrument is necessarily overbroad and there is a serious risk of overdeterrence. ${ }^{413}$ That danger of overdeterrence is compounded by the in terrorem effect that the mere existence of a noncompete agreement may have on an employee. Employees may not fully appreciate the nuances of noncompete law or be fearful of the costs of litigation. ${ }^{414}$ As a result, employees may be unwilling to engage in competitive activity, regardless of the enforceability of the noncompete agreement. Moreover, prospective employers may be deterred from hiring employees subject to noncompete agreements, fearful of potential legal claims for intentional interference with contracts or unfair competition.

In contrast to noncompete agreements designed to protect goodwill, it is difficult, if not impossible, to tailor a trade secret noncompete agreement so that it only prohibits an employee from competing in an

\footnotetext{
${ }^{413}$ See Blake, supra note 23, at 651 ("As a risk-distributing device the restraint on future employment is neither particularly efficient nor fair.").

${ }^{414}$ See, e.g., House of Vision, Inc. v. Hiyane, 225 N.E.2d 21, 25 (Ill. 1967) ("To stake out unrealistic boundaries in time and space, as the employer did in this case, is to impose upon an employee the risk of proceeding at his peril, or the burden of expensive litigation to ascertain the scope of his obligation.").
} 
unfair way, namely, by using or disclosing trade secrets. Only confidentiality and nondisclosure agreements directly prevent misappropriation. In fact, employee noncompete agreements tend to be standardized agreements whose restrictions are not bounded by trade secret usage, but rather by time, geography, and scope of activities restrained. ${ }^{415}$ Also, employers often have an incentive to draft overbroad noncompete agreements for several reasons. Anticipating or predicting what trade secret information needs to be protected and the types of harmful competitive activities in which an employee might engage at some future time is problematic. ${ }^{416}$ Moreover, in many states, courts will reform an overbroad noncompete agreement. ${ }^{417}$ The legal risks of imposing an overbroad agreement on employees, therefore, may be minimal in many jurisdictions. Thus, noncompete agreements designed to protect trade secrets will not be carefully tailored to prevent unfair competition, ${ }^{418}$ the result of which will be overdeterrence of employees and a potentially anticompetitive effect on the market.

\section{A New Policy Framework for Postemployment Restraints on Competition:} Utilizing the Inevitable Disclosure Doctrine to Balance the Competing Interests in Employee Mobility and Trade Secrets

Any change in the law of employee noncompete agreements should be sensitive to the overriding need to protect employee mobility and the positive and negative economic costs of enforcing noncompete agreements. Under our proposed framework, trade secrets would not be considered a protectable interest under employee noncompete agreements. Instead, our framework relies on nondisclosure and confidentiality agreements to protect trade secrets in the postemployment context, similar to the approach in California. Our framework deviates from the California

\footnotetext{
${ }^{415}$ See Rachel Arnow-Richman, Cubewrap Contracts and Worker Mobility: The Dilution of Employee Bargaining Power via Standard Form Noncompetes, 2006 Мich. Sт. L. Rev. 963, 980-81 (2006).

${ }^{416}$ Blake, supra note 23, at 699.

${ }^{417}$ See supra note 117.

${ }^{418}$ E.g., Comprehensive Techs. Int'l v. Software Artisans, 3 F.3d 730, 738-39 (1993) (reversing district court ruling that the noncompete agreement was "categorically" overbroad and enforcing prohibition against the employee "working for a competitor of [employer] in any capacity" because trade secrets were at stake), vacated and appeal dismissed per stipulation, No. 92-1837, 1993 U.S. App. LEXIS 28601 (4th Cir. Sept. 30, 1993).
} 
approach in that it not only permits, but relies heavily on, the inevitable disclosure doctrine to balance the competing interests in employee mobility and trade secret protection. ${ }^{419}$

Nondisclosure and confidentiality agreements, if enforced rigorously by the courts, prevent the unfair exploitation of trade secrets, while allowing free competition by former employees. The traditional arguments against this approach are threefold. First, there are procedural difficulties associated with establishing trade secret misappropriation. ${ }^{420}$ Therefore, traditional remedies may be difficult to secure, which will make it more likely that former employees will misappropriate trade secrets when they start competing firms or go to work for competitors. ${ }^{421}$ Second, there is a risk of underdeterrence if employment cannot be restrained. ${ }^{422}$ Finally, irreparable injury may occur if an employer cannot prevent in advance the use or disclosure of trade secrets by employees. ${ }^{423}$ The remedy of damages may not be adequate in some situations. Thus, an injunctive remedy preventing postemployment competition is critical to the protection of trade secrets.

However, the development of the inevitable disclosure doctrine, along with other changes in trade secret law, suggests that these drawbacks may not be as important as once thought. Trade secret owners have broad protection for trade secret information under the UTSA, ${ }^{424}$ adopted in the vast majority of states. ${ }^{425}$ The UTSA expands the scope of trade secret protection, which employers have used to protect the sort of soft manage-

\footnotetext{
${ }^{419}$ See supra notes $302-10$ and accompanying text for a discussion of the California approach.

${ }^{420}$ See supra note 43 and accompanying text. See also Everett J. Prescott, Inc. v. Ross, 390 F. Supp. 2d 44, 46 (D. Me. 2005) (noting that proving a violation of a nondisclosure agreement presents "evidentiary difficulties" (citing Bernier v. Merrill Air Eng'rs, 770 A.2d 97, 104 (Me. 2001))).

${ }^{421}$ See Rubin \& Shedd, supra note 354, at 96-97 (noting workers have an economic incentive for "opportunistic behavior" once they leave a firm in possession of valuable information).

${ }^{422}$ See Blake, supra note 23, at 669-70 ("Even in the best of good faith, a former technical or 'creative' employee working for a competitor, or in business for himself in the same or a related field, can hardly prevent his knowledge of his former employer's confidential methods or data from showing up in his work.").

${ }^{423} I d$.

${ }^{424}$ Unif. Trade Secrets Act $\S 1-11$ (amended 1985), 14 U.L.A. 434 (1990).

${ }^{425}$ See supra note 256 for a list of states that have adopted the UTSA.
} 
rial trade secrets in PepsiCo ${ }^{426}$ and EarthWeb. ${ }^{427}$ Also, the UTSA provides holders with substantial remedies, including multiple damages when misappropriation is willful ${ }^{428}$ and injunctive relief when there is evidence of an actual or threatened misappropriation. ${ }^{429}$ This protection has recently been fortified by the passage of the Economic Espionage Act, ${ }^{430}$ which imposes criminal penalties for trade secret misappropriation and economic espionage. Finally, the inevitable disclosure doctrine should provide the necessary injunctive relief when there is a high probability of trade secret misappropriation but no direct evidence of misappropriation.

Although the doctrine of inevitable disclosure has been criticized by both courts and commentators, ${ }^{431}$ the critique loses much of its force if employee noncompete agreements are not allowed to protect trade secret information. The primary criticism of the doctrine is that it creates a de facto noncompete agreement, without the employee's consent, and thereby expands the protection the employer has under a confidentiality or nondisclosure agreement. ${ }^{432}$ As a consequence, critics argue that the remedy upsets the delicate balance struck by employee noncompete law in terms of the parties' competing interests and threatens the employee's interest in mobility. ${ }^{433}$ But if the doctrine provides the sole means by which a noncompete injunction can be obtained, the employee's interest in mobility is more than adequately protected.

\footnotetext{
${ }^{426}$ Supra note 271 and accompanying text.

${ }^{427}$ Supra notes 312-24 and accompanying text.

${ }^{428}$ Unif. Trade Secrets Act $\$ 3$ (amended 1985), 14 U.L.A. 434 (1990). See also Lucini Italia Co. v. Grappolini, No. 01 C 6405, 2003 WL 1989605, at*58-59 (N.D. Ill. Apr. 28, 2003) (awarding $\$ 1$ million in punitive damages under the Illinois Trade Secret Act for willful misappropriation).

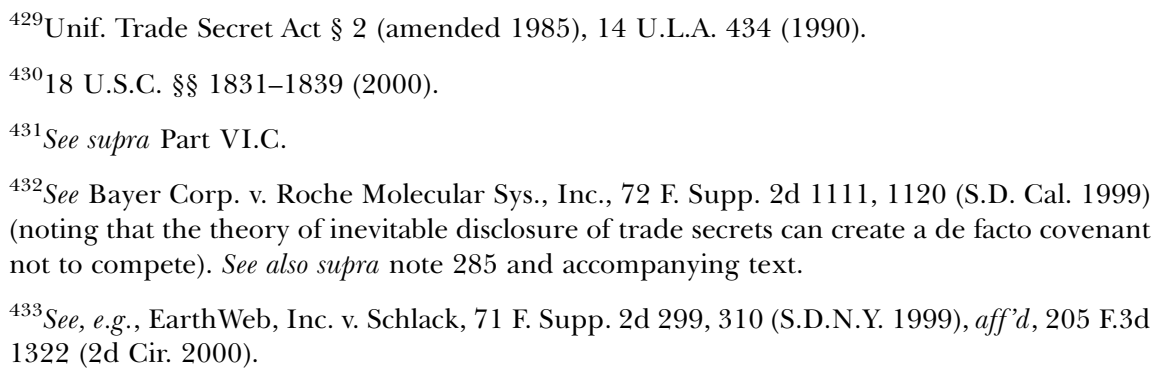


In fact, one can argue that employees are provided greater protection under this approach than under the common law reasonableness test. First, the proposed approach eliminates or minimizes the in terrorem effects of employee noncompete agreements. ${ }^{434}$ The doctrine may have a similar deterrent effect, but it will primarily affect employees contemplating competitive activities where trade secret misuse is probable, an effect that is necessary to protect the interests of trade secret holders and prevent unfair competition. Second, it substitutes a carefully framed injunction based on demonstrated necessity (inevitability) for what is often an overbroad noncompete agreement based only on the potential for trade secret misappropriation. If the employee's right to compete is going to be restricted because of such necessity, then the court should be able to fashion a more limited remedy than under an employee noncompete agreement, one that more directly considers the employee's interest in mobility and the probable harm to the employer's trade secrets.

Courts have been able to confine the use of the inevitable disclosure doctrine so as to ensure that the employer's trade secrets are protected while not unduly restricting the employee's freedom of mobility. By requiring a showing that disclosure of trade secrets is a virtual certainty, courts can ensure that injunctions on competition will not be imposed based merely on the potential of trade secret misappropriation. ${ }^{435}$ Most courts have adopted the position that inevitable disclosure will not be inferred from the mere knowledge of or exposure to proprietary business information. ${ }^{436}$ In determining inevitability, courts should also closely scrutinize claims of trade secret status, particularly the broad claims relating to soft trade secrets. ${ }^{437}$ Intimate and extensive knowledge of

\footnotetext{
${ }^{434}$ See supra note 414 and accompanying text for a description of the in terrorem effects of noncompete agreements.

${ }^{435}$ E.g., Cintas Corp. v. Perry, No. 03 C 8404, 2004 WL 2032124, at*58-59 (N.D. Ill. Aug. 20, 2004) (rejecting as mere speculation the employer's inevitable disclosure argument where there was no evidence of actual misappropriation during the eight months the former employee worked for a new employer).

${ }^{436}$ E.g., Omnitech Int'l, Inc. v. Clorox Co., 11 F.3d. 1316, 1325 (5th Cir. 1994) (“Certainly 'misappropriation' of a trade secret means more than simply using knowledge gained through a variety of experiences. ..."); APAC Teleservices v. McRae, 985 F. Supp. 852, 860-62 (N.D. Iowa 1997) (finding knowledge of trade secrets insufficient, even with evidence of untrustworthiness of the former employee).

${ }^{437}$ See, e.g., Square D Co. v. Handel, No. 04-C-775, 2005 U.S. Dist. LEXIS 21480, at *22-23 (E.D. Wis. Aug. 25, 2005) (questioning whether pricing information should be protected as a
} 
legitimate and highly valuable (and vulnerable) trade secrets should become a precondition to a finding of inevitable disclosure. Moreover, many courts have insisted on strong evidence of wrongful intent before concluding that misappropriation is truly inevitable. ${ }^{438}$ The emerging post-PepsiCo standard incorporates that key intent factor of the common law within its analytical framework. ${ }^{439}$

Courts applying a demanding standard of inevitable disclosure also have crafted limited injunctions, carefully considering the employer's and employee's competing interests. ${ }^{440}$ An illustrative example is DoubleClick, Inc. v. Henderson, ${ }^{441}$ in which the court granted a six-month noncompete injunction against former high-level executives of an Internet advertising business who intended to start up a competing business.

In DoubleClick, the former employees, David Henderson and Jeffrey Dickey, decided to leave DoubleClick, the dominant force in Internet advertising, to start a new company, Alliance Interactive Networks. ${ }^{442}$ Dickey was vice president of business development at DoubleClick. Henderson was vice president of North American advertising sales, responsible for managing DoubleClick's sales force and a member of the firm's management team. They were privy to sensitive information that DoubleClick claimed as trade secrets, including revenue projections, plans for future projects, pricing and product strategies, and databases with

trade secret except in extraordinary circumstances). See also Schwan's v. Home Run Inn, Inc., No. 05-2763, 2005 U.S. Dist. LEXIS 32879, at*16-17 (D. Minn. Dec. 9, 2005) (finding no inevitable disclosure where the employer did not specifically identify confidential information).

${ }^{438}$ See, e.g., FMC Corp. v. Cyprus Foote Mineral Co., 899 F. Supp. 1477, 1482-83 (W.D.N.C. 1995) (holding that North Carolina case law requires a showing of the employee's bad faith to grant an injunction under the doctrine of inevitable disclosure); Danielle Pasqualone, Note, GlobeSpan, Inc. v. O'Neill, 17 Berkeley Tech. L.J. 251, 268 (2002) (noting that most postPepsiCo cases require a showing of "dishonesty or bad faith" and citing examples).

${ }^{439}$ See supra notes 287-98 and accompanying text for a discussion of $H \& R$ Block Eastern Tax Services, Inc. v. Enchura, 122 F. Supp. 2d 1067 (W.D. Mo. 2000), and the inevitability-plus standard adopted by a number of courts following PepsiCo.

${ }^{440}$ E.g., Merck \& Co., Inc. v. Lyon, 941 F. Supp. 1443, 1464-65 (M.D.N.C. 1996) (enjoining the former employee only from discussing specific trade secret information with the new employer).

${ }^{441}$ No. 116914/97, 1997 WL 731413 (N.Y. Sup. Ct. Nov. 7, 1997).

${ }^{442} I d$. at *3. 
client information. ${ }^{443}$ In July 1977 Henderson and Dickey started planning for their new company by developing a business plan and seeking out investors. ${ }^{444}$ In September 1997 Henderson was fired after their plan was discovered. ${ }^{445}$ His confiscated laptop contained Alliance's business plan and a "Stakeholder Positioning Analysis," which contained information on DoubleClick's contracts that Henderson and Dickey apparently intended to use in luring away advertising clients from DoubleClick. ${ }^{446}$ Also, while working for DoubleClick, Henderson and Dickey had solicited one of its clients for their new business and solicited financing from one of DoubleClick's competitors. ${ }^{447}$

DoubleClick sought an injunction against the planned advertising venture based on misappropriation of trade secrets and breach of loyalty. ${ }^{48}$ The court first examined whether the information to which Henderson and Dickey were privy constituted protected trade secrets. ${ }^{449}$ Henderson and Dickey argued that the information was not confidential because it was publicly disclosed by Doubleclick. ${ }^{450}$ Although some advertising rates were posted on DoubleClick's Web sites, the court found that DoubleClick did not reveal the actual financing arrangements with clients nor other information, such as the number of hits on specific Internet advertisements. ${ }^{451}$ The court concluded that there was an actual misappropriation of trade secrets and a "high probability of inevitable disclosure," given the improper use by Henderson and Dickey, the planned venture, and their "cavalier attitude toward their duties to their former employer." 452

\footnotetext{
${ }^{443} I d$. at $* 2$.

${ }^{444} I d$. at $* 3$.

${ }^{445} I d$.

${ }^{446} I d$. at $* 5$.

${ }^{447} I d$. at $* 6$.

${ }^{448}$ Id. at $* 1$.

${ }^{449}$ Id. at ${ }^{*} 3-* 6$.

${ }^{450}$ Id. at $* 4$.

${ }^{451} I d$.

${ }^{452} I d$. at *5-6.
} 
In fashioning a remedy, however, the court rejected DoubleClick's request for a broad, one-year injunction. It found that the requested injunction was not sufficiently tailored in several respects. First, it would have prevented Henderson and Dickey from working in any advertising position or firm, even if the position or business was not in the Internet advertising arena. ${ }^{453}$ Second, the proposed one-year period was too long given the rapid speed with which the online advertising environment changes. ${ }^{454}$ Therefore, it granted an injunction for only six months and limited it to direct competitive activity. ${ }^{455}$

In contrast to the approach of the court in DoubleClick, courts applying the traditional common law reasonableness test frequently enforce employee noncompete agreements regardless of any demonstrated need to protect trade secrets. A recent example is Nike, Inc. v. McCarthy. ${ }^{456}$ McCarthy, a twenty-year employee of Nike signed a noncompete agreement that prevented him from working for a competitor for a one-year postemployment period. ${ }^{457}$ At the time of his departure from Nike, McCarthy was in the position of global sales for Brand Jordan. ${ }^{458}$ Facing what he believed was an imminent demotion, he took a position with Reebok as vice president for U.S. footwear sales and marketing. ${ }^{459}$ In Nike's suit to enforce the noncompete agreement, the court strictly enforced the agreement without any consideration of the legitimacy of the trade secret claims or necessity of an injunction. In fact, the court rejected any consideration of whether his employment resulted in a threat of trade secret misappropriation. ${ }^{460}$ Concluding that a severance package

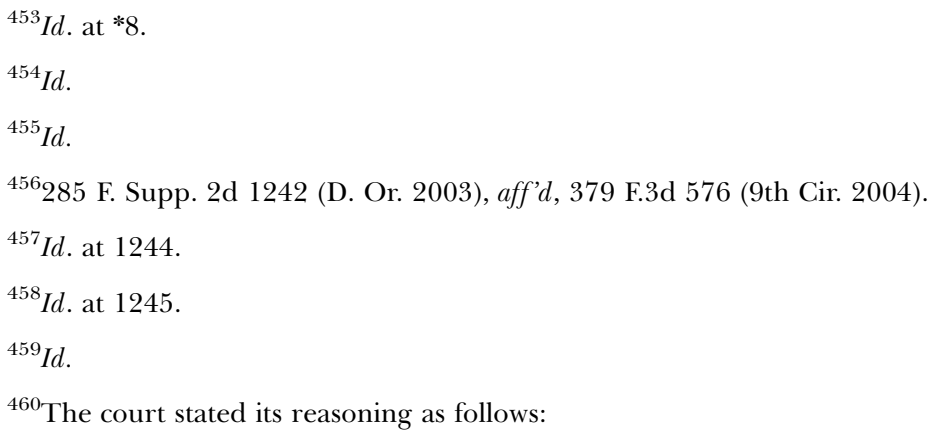

The fact that defendant may not have used any confidential information in his new position with Reebok only shows that he has not violated other provisions of the noncompete agreement. What remains is that the parties agreed to abide by the terms of the non-compete regardless of any demonstrated specific need. I allowed considerable 
was sufficient to protect McCarthy, the court approved a broad injunction under the terms of the noncompete agreement. McCarthy was restrained from taking any position at Reebok or any other business in the athletic footwear or apparel business that was a competitor of Nike or its affiliated entities. $^{461}$

A comparison of cases like DoubleClick and Nike suggests that the inevitable disclosure doctrine may establish a preferable legal framework within which to determine whether a former employee should be prevented from competing and, if so, how extensive that restriction should be in order to protect an employer's trade secrets. Employee noncompete agreements often overprotect trade secrets at the expense of the employee's interest in mobility and society's interest in open competition. Inevitable disclosure, although criticized by commentators and courts, may provide the flexibility necessary to correctly balance the rights of employers and employees with regard to trade secrets and postemployment competition.

\section{CONCLUSION}

This article suggests that an alternative policy framework is necessary to align the law of employee noncompete agreements with the changes occurring in the workplace and the economy. Recent cases demonstrate that the common law reasonableness test can be adapted to prevent overbroad noncompete agreements designed to protect the goodwill of a former employer. By limiting that goodwill interest to the customer relationships developed by the former employee, the "sphere of customer influence," the courts can limit the breadth of noncompete covenants in this setting. If the power of reformation is similarly restricted by the courts, a proper balance will be struck between an employee's interest in mobility and the employer's interest in protecting its customer relationships.

leeway in the testimony and evidence regarding the circumstances surrounding defendant's separation from Nike and his assumption of duties with Reebok for the limited purpose of determining whether enforcement of the contract would be unconscionable and I find nothing to support such a conclusion.

Id. at $1245-46$.

${ }^{461} I d$. at $1247-48$. 
Our proposed framework employs a new policy approach for the protection of trade secrets in the postemployment context. We propose a decoupling of trade secret protection from employee noncompete law. Under this proposal, trade secrets would not be considered a legitimate interest justifying an employee noncompete agreement. Trade secrets would continue to be protected from actual or threatened misappropriation under confidentiality agreements and trade secret laws. Most importantly, courts would be empowered to prevent employment of a former employee under the inevitable disclosure doctrine. Such an approach would support a climate of employee mobility and information sharing while providing businesses with an appropriate level of protection for their goodwill and trade secrets. 